\title{
Türkiye’de Döviz Kuru Hareketleri ve Kamu Borcu İlişkisi
}

\author{
Umut AKDUĞAN*
}

\section{$\ddot{O} \mathbf{z}$}

Kamu borcu ile döviz kuru arasındaki ilişki, iki farklı açıdan ele alınabilmektedir: i) Döviz kuru hareketleri, döviz cinsinden veya dövize endeksli borç stoku kanalıyla toplam kamu borcu miktarını değiştirebilmektedir. ii) Kamu borcundaki artış, ekonomiye ilişkin risk algısını artırıp yabancı sermaye çıkışına neden olarak, döviz kurunu yükseltebilmektedir. Bu çalışmada; Türkiye'de 2001 krizi sonrası dönemde, kamu borcu ile döviz kuru arasındaki ilişkinin yönü, borç stoku bileșenleri kapsamında ayrıntılı olarak incelenmiştir. Bu bağlamda, 2002-2019 dönemi aylık verileri kullanılarak değişkenler arasındaki uzun dönemli ilişkiler Johansen eșbütünleşme yaklaşımıyla analiz edilmiştir. Devamında vektör hata düzeltme (VEC) modelleri tahmin edilerek, değișkenler arasındaki kısa ve uzun dönem nedensellik ilişsileri VECM Granger nedensellik testi ile araştırılmıştır. Değişkenler arasındaki dinamik ilişkiler ise VAR modeline dayalı etki-tepki ve varyans ayrıştırma analizleri ile incelenmiştir. Bulgular; toplam borç stoku, dış borç stoku ve döviz cinsinden toplam borç stokunun reel döviz kuru değişkeni üzerinde anlamlı etkisinin olduğunu, diğer taraftan reel döviz kuru değişimlerinin iç borç stoku ve Türk Lirası cinsinden toplam borç stoku üzerinde etkili olduğunu göstermektedir. Bu sonuçlar, döviz cinsinden kamu borcu ve toplam borç yükü artışının, risk algısını olumsuz etkileyerek döviz kuru şoklarına neden olabileceğine işaret etmektedir. Anahtar Kelimeler: Kamu Borcu, Reel Döviz Kuru, VAR Analizi, Johansen Eşbütünleşme, VECM Granger Nedenselliği

\section{The Relationship Between Exchange Rate Movements and Public Debt in Turkey}

\begin{abstract}
The relationship between public debt and exchange rate can be considered from two different perspectives: i) Exchange rate movements can change the amount of total public debt through foreign currency or foreign currency indexed debts. ii) The rise in public debt may increase the risk perception regarding to the economy and this may increase the exchange rate by causing foreign capital outflow. In this study; in the period after the 2001 crisis in Turkey, the direction of the relationship between the exchange rate and public debt has been examined within the scope of debt components. In this context, long-term relationships between variables are analyzed with the Johansen cointegration approach, using monthly data for the period of 2002-2019. Then, vector error correction (VEC) models are estimated and short and long term causality relationships between variables are examined with VECM Granger causality test. Dynamic relationships between variables are analyzed with impulse-response and variance decomposition analyzes based on the VAR model. According to findings; total public debt, external public debt and total debt denominated with foreign currency have a significant effect on the real exchange rate variable, on the other hand real exchange rate movements affect domestic public debt and total debt denominated in Turkish Lira. These results indicate that the increase in public debt denominated in foreign currency and the rise in total debt burden may negatively affect the risk perception and this may cause exchange rate shocks.
\end{abstract}

Keywords: Public Debt, Real Exchange Rate, VAR Analysis, Johansen Cointegration, VECM Granger Causality.

Received/Geliş: 26.12.2019

Accepted/Kabul: 14.05.2020

Etik Kurul Başvuru Tarihi: 28.04.2020

Etik Kurul Rapor Tarihi: 06.05.2020

\footnotetext{
* Dr. Öğr. Üyesi, Trakya Üniversitesi, İktisadi ve İdari Bilimler Fakültesi, Maliye Bölümü, umutakdugan@trakya.edu.tr, (D/0000-0001-8659-541X

(Makale türü: Araştırma makalesi)
} 


\section{Giriş}

Bir maliye politikası aracı olarak kamu borçlanması açısından bakıldığında temel amaç, devletin finansman ihtiyacının orta ve uzun vadede kabul edilebilir bir risk ve düşük maliyetle karşılanarak, borçların sürdürülebilirliğinin sağlanmasıdır. Kamu borç yönetiminde dikkat edilmesi gereken başlıca riskler, borcun vade yapısı ve maliyeti ile ilişkili olan faiz oranı riski, finansman yükümlülükleri ile ilişkili likidite riski, temerrüde düşme olasıllığı ile ilişkili kredi riski ve son olarak döviz kuru riski şeklinde sıralanmaktadır (Papaioannou, 2009).

Borç yapısı ile ilgili olan kur riskinin ölçülmesi ve yönetilmesi oldukça önemlidir. Kamu borç stokunun önemli bir kısmının döviz cinsinden veya kur değişimlerinden etkilenen başka enstrümanlardan oluşması, borç portföyünün maruz kalacağı döviz kuru riskini arttıracaktır. Dolayısıyla, özellikle ekonomik kriz dönemlerinde döviz kurlarında yaşanan dalgalanmalar kamu kesiminin borç miktarını etkileyebilmektedir. $\mathrm{Bu}$ açıdan, risk yönetimini temel alan borç yönetimi, kur kaynaklı krizlerin etkilerini azaltma ve borçların sürdürülebilirliği noktasında büyük öneme sahiptir (Nart, 2015). Kur riskinden korunmak ve aynı zamanda kamu borcunun sürdürülebilirliği için, borç portföyünün riskini arttıran kısa vadeli, döviz cinsinden ya da enflasyona endeksli borçlanma araçları yerine, uzun vadeli, sabit oranlı ve ulusal para cinsinden borçlanma araçlarının daha fazla tercih edilmesi gerekmektedir (Ulusoy ve Kara, 2017). Ancak, gelişmekte olan ülkeler ve diğer pek çok ülke için, böyle bir tercihin yapılabilmesi çeşitli sebepler nedeniyle oldukça zor görünmektedir.

Bu çalışmada genel olarak, Türkiye'de 2001 krizi sonrası dönemde, döviz kuru hareketleri ile kamu borç stoku arasındaki ilişkinin yönü incelenecektir. Dolayısıyla, araştırılacak hipotezler şu şekilde ifade edilebilmektedir: i) Kamu borç portföyü döviz kuru riskine maruz kalmaktadır ve reel döviz kuru değişimleri kamu borcunun kompozisyonunu ya da miktarını değiştirmektedir, ii) Kamu borcundaki değişim, uluslararası piyasalarda ekonomiye ilişkin risk algısını etkileyerek, döviz kuru şoklarına neden olabilmektedir.

Bu kapsamda, Türkiye'de hangi varsayımın geçerli olduğunu tespit etmek amacıyla, son yirmi yıldaki döviz kuru hareketleri ile kamu borcunun yapısındaki değişim ekonometrik yöntemlerle araştırılacaktır. Çalışmanın ikinci bölümünde, döviz kuru ile kamu borcu arasındaki ilişkinin teorik altyapısına, üçüncü bölümünde ise Türkiye'de 2001 sonrası dönemde kamu borç stokundaki gelişmelere ve reel döviz kuru değişimlerine yer verilecektir. Dördüncü bölümde, çalışmanın hipotezleri VAR modelleri ile test edilerek elde edilen bulgular özetlenecek, son bölümde ise ulaşılan sonuçlar değerlendirilecektir.

\section{Kamu Borcu - Döviz Kuru İlişkisine Teorik Bakış}

Döviz kuru değişimleri ve kamu borçları arasındaki ilişki temelde iki mekanizma tarafından belirlenmektedir. Bunlardan birincisi, döviz kuru değişimlerinin kamu borcu 
üzerindeki etkisini açıklarken, ikincisi ise kamu borç stokundaki değişimlerin döviz kuruna etkisini ele almaktadır (Schonerwald da Silva ve Vernengo, 2007).

Döviz kurunda meydana gelen değişimlerin kamu borç stokunu etkileme derecesi, genellikle yabancı para cinsinden borçların fazla olduğu ülkelerde daha yüksektir. Çünkü, döviz kuru oynaklığının fazla olmasının ya da ani ve yüksek oranlı kur artışlarının finansal istikrar üzerindeki olumsuz etkisi, genellikle kamu kesimine de yansımaktadır. Döviz cinsinden borcun, toplam kamu borç stoku içindeki payının yüksek olduğu ülkelerde, yaşanan kur şokları kamu borçlanmasının sürdürülebilirliğini negatif etkileyebilmektedir. Dolayısıyla, ulusal para birimi cinsinden ve uzun vadeli borçlanamayan ülkelerde ${ }^{*}$, kamu borç yönetiminden sorumlu otoritelerin döviz kuru hareketlerini dikkatle izlemesi ve buna göre hareket etmesi gerekmektedir. $\mathrm{Bu}$ noktada, özellikle gelişmekte olan ve finansal kırılganlıkları fazla olan ülkelerde döviz cinsinden varlıkların arttırılamaması durumunda, ulusal para cinsinden borçlanma piyasalarının geliştirilmesi önem kazanmaktadır (Margolin, 2007). Yurtiçi finansal piyasalarda derinliğin sağlanamadığı ve yerel para birimi cinsinden borçlanma piyasalarının yeterince gelişmediği ülkelerde, orijinal günahın da azami seviyede olması doğal bir durumdur. Finansal piyasalardaki olumsuzluklara ilaveten, uygulanan para politikasına bağlı olarak iç piyasada faiz oranlarının yüksek olması durumunda, bu gibi ülkeler için yurt dışı piyasalarda daha uzun vadeli ve daha düşük maliyetli borçlanma imkânı ortaya çıkacak, bu da daha cazip olan döviz cinsinden borçlanmayı arttıracaktır (Yavuz, 2009). Kamu kesimi ile birlikte, özel sektörün de toplam borç stoku içerisinde döviz cinsinden borç oranının artması, aynı zamanda ulusal paranın devalüe edilmesi anlamına gelmektedir ve bu durumda diğer pek çok makroekonomik göstergenin olumsuz etkilenme ihtimali bulunmaktadır. Bu nedenle; uluslararası piyasalarda para birimleri güçlü olmayan ve dolayısıyla borç stokunun önemli bir kısmı yabancı para cinsinden (orijinal günahı yüksek) olan gelişmekte olan ülkelerde, döviz kuru dinamiklerinin belirlenmesi oldukça önemlidir (Schonerwald da Silva ve Vernengo, 2007).

Yabancı para cinsinden borçlanmanın diğer bir nedeni de, döviz girdisi kısıtlı olan ekonomilerde yabancı para cinsinden borcun olması ve bu borcun geri ödenebilmesi için döviz cinsinden borçlanmanın bir gereklilik olmasıdır. Türkiye gibi genel olarak cari işlemler açığı veren, yani net döviz fazlasına sahip olmayan ülkelerde bu şekildeki bir borç sarmalı, döviz cinsinden borçlanmanın artarak devam etmesine neden olmaktadır (Margolin, 2007). Bu bağlamda, özel sektör ve finansal kuruluşlar için oldukça önemli olan varlık ve yükümlülükler arasındaki kur uyumu, kamu kesimi ve kamu borçlanma politikaları açısından da büyük öneme

\footnotetext{
* Eichengreen ve Hausmann (1999), bu gibi ülkelerdeki söz konusu durumu "orijinal günah" olarak adlandırmaktadır. Hausmann ve Panizza (2003)'e göre; orijinal günah kavramı, bir ülkenin iç piyasada ulusal parası cinsinden uzun vadeli borçlanamaması ve uluslararası piyasalarda da yine ulusal para birimi cinsinden (kısa vadeli olsa bile) borçlanamamasını ifade etmektedir.
} 
sahiptir. İhracattaki artış ya da ülkeye daha fazla doğrudan yabancı yatırımın çekilmesi gibi ödemeler dengesine pozitif katkı veren faaliyetler sonucunda sağlanan döviz girdilerinin, diğer değişkenler sabitken, borç stokunun para birimi cinsinden kompozisyonunu olumlu etkilemesi ve döviz cinsinden borç miktarını azaltması beklenmektedir.

Diğer taraftan, döviz kuru değişimlerinin kamu borç stoku üzerindeki etkisi, dolaylı olarak ödemeler dengesi kanalıyla da ortaya çıkabilmektedir. Eğilmez (2012)'in de belirttiği gibi; kamu gelirlerinin ağırlıklı olarak dolaylı vergilere dayandığ 1 Türkiye gibi ülkelerde, döviz kurundaki bir artış ithalatı azaltarak, ithalat üzerinden tahsil edilen vergilerde de bir düşüşe neden olacaktır. Bu durumun, daha büyük bütçe açığına ve dolayısıyla kamu borç miktarında da artışa neden olması kuvvetle muhtemeldir.

Döviz kuru ile kamu borç stoku arasındaki ilişkinin diğer yönü ise, borç stokundaki değişimin kur üzerindeki etkisini açıklamaktadır. Buna göre, kamu borç stokundaki artış, borç yükümlülüklerinin yerine getirilememesi veya temerrüt olasılığının artması düşüncesi ile birlikte, ülke riskine ilişkin algıyı olumsuz etkileyebilecektir. Bu durum ise, ülke ekonomisinden önemli miktarda yabancı sermaye çıkışına ve bunun sonucunda döviz kurunda yukarı yönlü şoklara yol açabilecektir (Schonerwald da Silva ve Vernengo, 2007).

Öte yandan, reel döviz kurunun en önemli işlevlerinden birisi, değişen piyasa koşullarına ayak uydurabilmeleri için üreticilere ve tüketicilere yol göstermesi, piyasa ekonomisinin temeli olan göreceli fiyatları belirlemesidir (Neven ve Wyplosz, 1999). Bu açıdan reel döviz kuru, bir ekonominin uluslararası rekabet gücünü etkileyen ve aynı zamanda yabancı yatırımcılar için gösterge olarak görülen önemli bir faktördür. Nitekim aşırı borç yükü ve bütçe açıklarının sürdürülemez bir hal alması, uluslararası yatırımcılar açısından negatif algıya ve döviz kurunda oynaklığa neden olacak, reel döviz kurundaki belirsizlik ise uluslararası rekabet gücünü olumsuz etkileyerek problemin bir kısır döngüye girmesine yol açacaktır (Sène, 2004).

Bir diğer açıdan bakıldığında, genellikle gelişmekte olan ülkeler ulusal para birimleri cinsinden dış borç alamadığından, mevcut dış borçların döviz cinsinden ödenmesi gerekmektedir. Bu sebeple, dış borç ödeme dönemlerinde döviz çıkışı meydana gelecek ve döviz talebinde bir artış gerçekleşecektir. Diğer taraftan, dış borçlanmanın yapıldığı dönemlerde ise, ekonomiye döviz girdisi sağlanacaktır. Dolayısıyla, belirli dönemlerde meydana gelen döviz arz ve talebindeki dalgalanmaların da döviz kurunu etkileme eğilimi bulunmaktadır. Krugman (1988)'da ifade edildiği gibi, uluslararası sermaye akımlarının arttığı veya dış borçlanmadan kaynaklanan döviz girişinin fazla olduğu durumlarda, uzun vadede reel döviz kurunun ayarlanması ihtiyacı ortaya çıkabilmektedir. Sonradan bu tartışma, tam sermaye hareketliliğinin olduğu gelişmekte olan ülkelerde uygulanması gereken döviz kuru rejiminin belirlenmesi noktasına genişletilmiştir. 
$\mathrm{Bu}$ bağlamda, dış borcun yüksek olmasının, otomatik dengeleyici olarak esnek döviz kuru rejiminin tercih edilmesine yol açabileceği ifade edilmektedir (Sène, 2004).

\section{Türkiye’de 2001 Krizi Sonrası Kamu Borcunun Yapısı ve Döviz Kuru Hareketleri}

Türkiye'de 2001 yılında döviz çıpası sisteminin terk edilip dalgalı kur rejimine geçilmesinden sonraki dönemde, döviz kuru değişimlerinin kamu borç yönetimi açısından önemini kamu borç stokunun yapısı ile ilişkilendirmek gerekmektedir. Çünkü borç stoku içerisinde döviz cinsinden ya da dövize endeksli borçların oranının fazla olması durumunda, borç portföyünün maruz kalacağı kur riski artacak ve borç yönetimi açısından kur hareketleri dikkat edilmesi gereken önemli bir değişken konumuna gelecektir. İncelenen dönemde, kamu borç stoku içinde döviz ve dövize endeksli borçların önemli bir paya sahip olduğu Şekil 1'de görülmektedir.

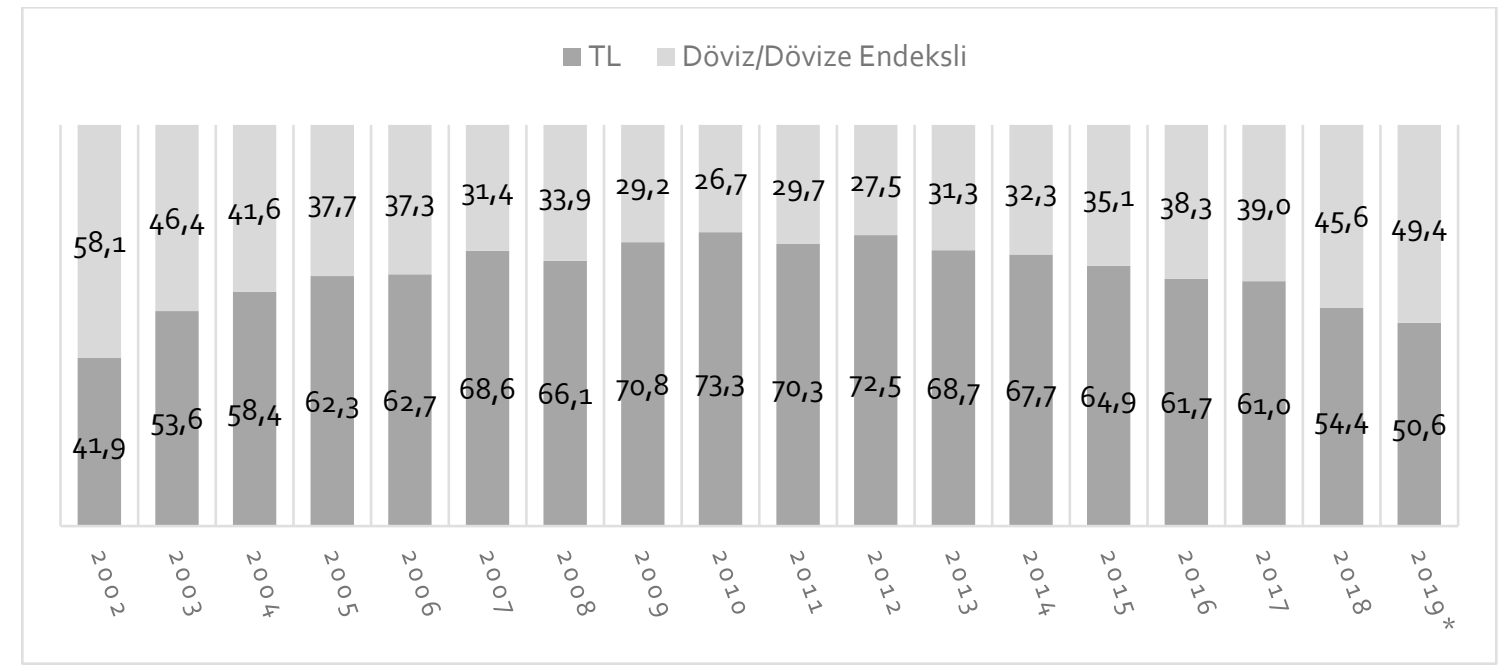

Şekil 1: Merkezi Yönetim Borç Stokunun TL/Döviz Kompozisyonu (\%)

Kaynak: T. C. Hazine ve Maliye Bakanlığı - Merkezi Yönetim Borç İstatistikleri (https://www.hmb.gov.tr/ kamu-finansmani-istatistikleri)

(*) Ekim ayı itibarıla

2000 yılında başlayan ve devalüasyonla sonuçlanan başarısız istikrar programı uygulamasının ardından, piyasalarda ciddi bir likidite krizi yaşanmış ve döviz talebi önemli miktarda artmıştır. Bunun sonucunda Hazine, 2001 yılında bankaların varlıkları arasında bulunan TL cinsinden Devlet İç Borçlanma Senetleri (DİBS)’ni dövize endeksli hale getirmiştir. Bu işlem ile birlikte, var olan döviz cinsinden dış borçların yanına iç borçların dövize endeksli kısmı da eklenmiş, toplam borç stoku içinde döviz cinsinden borçların oranı artarak 2002 y1lında \%58,1'e ulaşmıştır. Sonraki yıllarda bu oranın düşme trendine girdiği ve küresel kriz sonrası 2009-2012 döneminde \%30’un altına indiği görülmektedir (Bkz. Şekil 1).

2002 y1lından itibaren döviz kurlarının kademeli olarak düştüğü göz önünde bulundurulduğunda (Bkz. Şekil 2), bu dönemde döviz cinsinden borç oranının düşmesinin sadece geri ödemelerden kaynaklanmadığı anlaşılmaktadır. Döviz kurlarının TL karşısında değer 
kaybetmesi ile birlikte, döviz cinsinden ve dövize endeksli borçların cari kurdan yeniden değerlenmesi sonucunda borç stoku içindeki payı azalmıştır (Uzunoğlu, 2005). Şekil 2'de gösterilen reel efektif döviz kuru endeksinin değişimine bakıldığında, yabancı para cinsinden borç stoku oranı ile arasındaki korelasyon da bu durumu destekler niteliktedir. 2002-2010 döneminde reel efektif döviz kurunun (kur şoklarından kaynaklı aşağı ve yukarı yönlü sert hareketler olmakla birlikte) kademeli olarak arttığı (yani döviz kurlarının düştüğü), bununla birlikte, aynı dönemde toplam borç stoku içinde yabancı para cinsinden borcun oranının da gerilediği görülmektedir. 2010 y1lı sonrasında ise, reel efektif döviz kurunun düşme (döviz kurlarının yükseliş) trendine girdiği, döviz cinsinden borç oranının da artmaya başladığı Şekil 1 ve Şekil 2'den izlenmektedir.

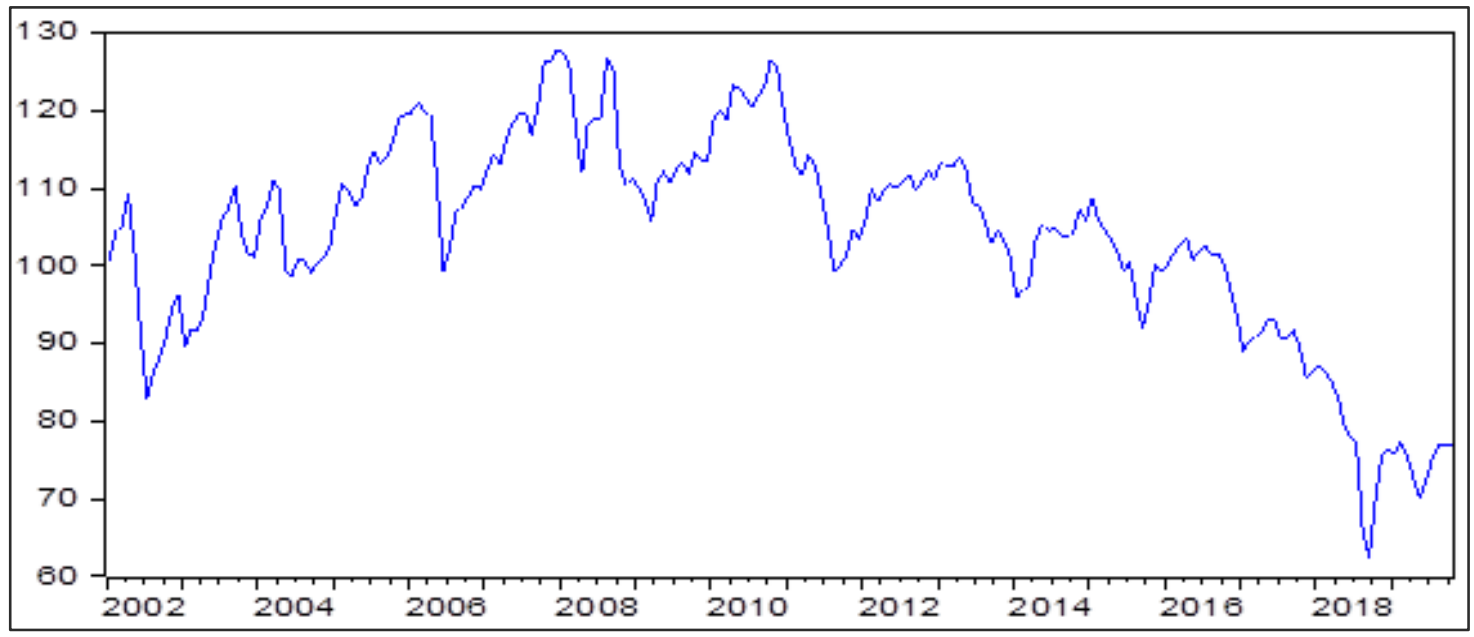

Şekil 2: TÜFE Bazlı Reel Efektif Döviz Kuru (2003=100)

Kaynak: TCMB - https://evds2.tcmb.gov.tr/

Bir diğer önemli nokta ise, iç borç stoku içerisindeki döviz cinsi borçların payındaki değişimdir. 2002-2009 döneminde dış borçların toplam borç stoku içindeki oranı ile yabancı para cinsinden borçların toplam borç stoku içindeki oranı arasındaki fark dikkat çekicidir. Örneğin 2002 yılı sonu itibariyle toplam borç stoku içinde döviz cinsi/dövize endeksli borçların payı \%58,1 iken, yine toplam borç stoku içinde dış borçların payının \%38,4 olduğu Tablo 1'de görülmektedir. Daha sonra aradaki bu fark giderek kapanmış, 2011 yılında, yabancı para cinsinden borç oranı, dış borç stokunun toplam borç stoku içindeki oranına neredeyse eşitlenmiştir. Bu noktadan hareketle, yabancı para cinsinden iç borçların, toplam iç borç stoku içindeki payı yıllar itibariyle hesaplanarak Şekil 3'deki grafik oluşturulmuştur.

2001 krizinden sonraki ilk yıllarda yabancı para cinsinden iç borçların payının yüksek olduğu, ancak bu oranın giderek düştüğü Şekil 3'de görülmektedir. $\mathrm{Bu}$ durumun ortaya çıkmasında, daha önce de ifade edilen, 2001 yılında Hazine'nin Türk Lirası cinsinden DİBS'leri dövize endeksli hale dönüştürmesinin etkisi büyüktür. Diğer taraftan, bu dönemde Türk Lirası'nın değerlenmesinin de, döviz cinsinden iç borçlanmayı arttırıcı etkisi bulunmaktadır. Çünkü, değerli Türk Lirası ile borçlanmaya yüksek reel faiz ödeyen Hazine için, döviz kurunun düşmesi ile 
yabancı para cinsinden borçlanmaya düşük reel faiz ödemek daha cazip hale gelmiştir (Uzunoğlu, 2005). Dolayısıyla, döviz kurunun düşmesi ile birlikte reel borçlanma maliyetini indirmek için, döviz cinsinden veya dövize endeksli iç borçlanmanın tercih edildiği anlaşılmaktadır.

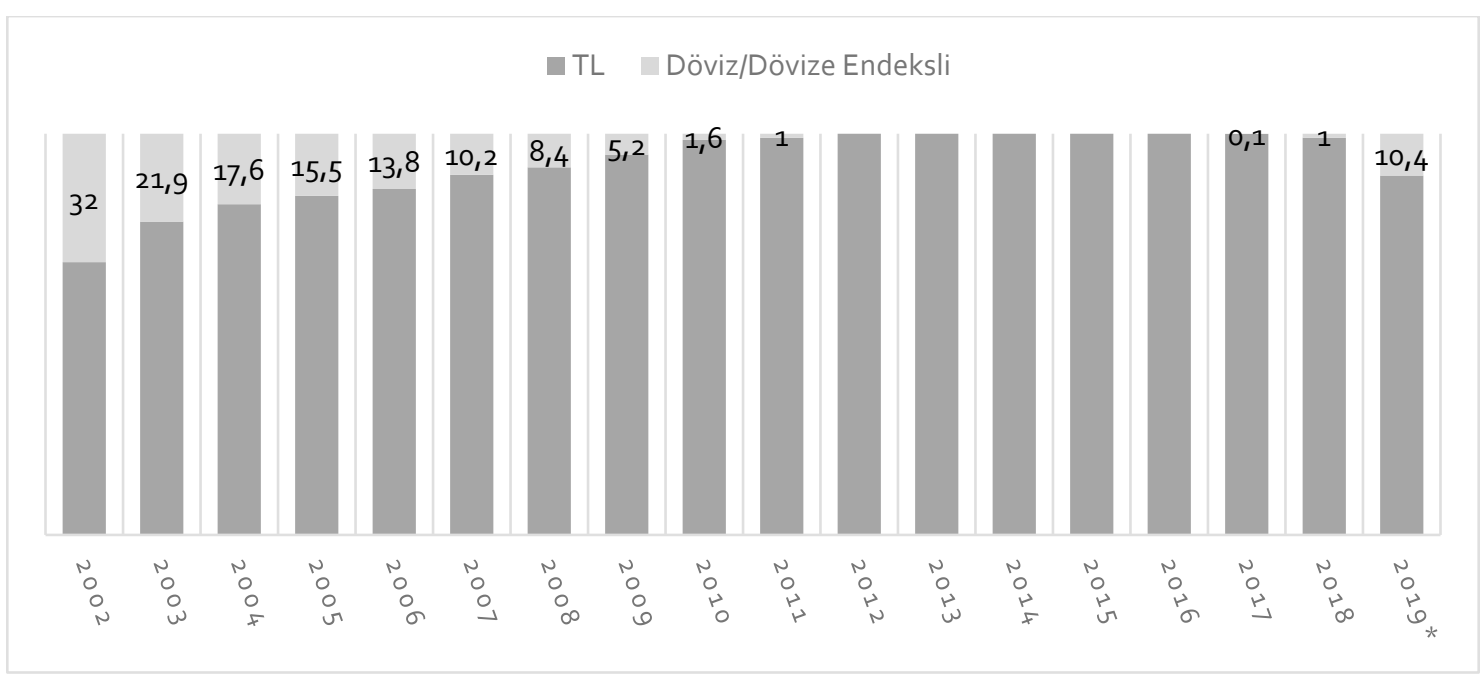

Şekil 3: İç Borç Stoku İçinde Döviz Cinsinden/Dövize Endeksli Borçların Oranı (\%)

Kaynak: T. C. Hazine ve Maliye Bakanlığı - Merkezi Yönetim Borç İstatistiklerinden faydalanılarak hesaplanan verilerle yazar tarafindan oluşturulmuştur.

(*) Ekim ayı itibarıyla

Hazine'nin gelirlerinin, özellikle vergi gelirlerinin, Türk Lirası cinsinden olduğu düşünüldüğünde, döviz cinsinden iç borçlar Hazine'nin varlıkları ile yükümlülükleri arasında uyumsuzluğa sebep olarak, döviz açığının ortaya çıkmasına neden olmuştur. Bu durumda da, borç portföyünün maruz kaldığı kur riski artmıştır. Neyse ki, yabancı para cinsinden iç borçların, iç borç stoku içindeki payı giderek azalmış, 2012 yılında iç borç stokunun tamamı Türk Lirası cinsinden gerçekleşmiş̧ir. 2008 yılındaki küresel krize rağmen bu tablonun ortaya çıkmasında, kamu bütçesi açısından mali disiplinin sağlanması ve bu konuda ısrarcı olunmasının etkili olduğu düşünülmektedir.

Tablo 1'de yer alan kamu borç istatistiklerine bakıldığında; borç stokundaki kademeli artışa rağmen, kamu borç stokunun GSYH'ye oranında (borç yükünde) 2001 sonrasında meydana gelen iyileşmede, sağlanan bütçe disiplini ve kamu borç yönetimindeki olumlu değişikliklerin etkisi büyüktür. 2001 krizi sonrasında, Türkiye ekonomisinin en önemli kazanımlarından birisinin maliye politikası ve borç yönetimi alanında olduğu bilinmektedir. Ekonominin güçlü yanlarından biri haline gelen mali disiplin ile birlikte, kamu borcu ve kamunun reel borçlanma maliyetleri uzunca bir süre düşük düzeylerde kalmış, borçlanma vadeleri de uzamıştır. Diğer bir deyişle, Türkiye ekonomisini 2001 krizine götüren temel sorunlar ortadan kalkmıştır (Özatay ve Sak, 2019). Bu olumlu gelişmeler sayesinde, Türkiye yurtdışı piyasalarda önceki dönemlere göre daha düşük maliyetlerle ve daha uzun vadelerle borçlanma imkanı bulmuş, kamu borçlanma araçları 
ise nispeten riskten arındırılmış getiri sunan cazip yatırım araçları haline gelmiştir (Güngen, 2015).

2001 krizi ile çok yüksek seviyelere çıkan iç ve dış borç yükünün, kriz sonrasında tekrar düşüşe geçtiği Tablo 1'den görülmektedir. 2008 küresel krizi ile birlikte borç yükünde artışlar meydana gelmiş (örneğin, 2008'de \%38,3 olan toplam borç yükü 2009 yılında \%44,2'ye çıkmıştır), bu artışın ardından iç borç yükü tekrar düşmeye başlamıştır. Buna karşın, dış borç yükünde önemli bir azalma meydana gelmediği, hatta 2014 yılı sonrasında bu oranın kademeli olarak arttığı, 2019 yılına gelindiğinde de bu artış trendinin devam ettiği görülmektedir. Ortaya çıkan bu durum ile birlikte, Amerikan Doları cinsinden dış borç stokundaki yükselme, kamu kesiminin dış borcunda reel bir artış olduğunu ve bu artışın sadece meydana gelen döviz kuru şokları ile açıklanamayacağını göstermektedir.

Tablo 1: Merkezi Yönetim Borç Stoku İstatistikleri

\begin{tabular}{|c|c|c|c|c|c|c|c|c|c|c|}
\hline & \multicolumn{3}{|c|}{ İç Borç Stoku } & \multicolumn{4}{|c|}{ Diş Borç Stoku } & \multicolumn{3}{|c|}{ Toplam Borç Stoku } \\
\hline & $\begin{array}{l}\text { Milyar } \\
\text { TL }\end{array}$ & $\%$ & $\begin{array}{c}\text { Borç } \\
\text { Yükü } \\
(\%)\end{array}$ & Milyar TL & $\%$ & $\begin{array}{c}\text { Borç } \\
\text { Yükü } \\
(\%)\end{array}$ & $\begin{array}{l}\text { Milyar } \\
\text { USD }\end{array}$ & $\begin{array}{l}\text { Milyar } \\
\text { TL }\end{array}$ & $\%$ & $\begin{array}{c}\text { Borç } \\
\text { Yükü } \\
(\%)\end{array}$ \\
\hline 2002 & 149,9 & 61,6 & 41,7 & 93,2 & 38,4 & 25,9 & 56,8 & 243,1 & 100 & 67,7 \\
\hline 2003 & 194,4 & 68,6 & 41,5 & 88,8 & 31,4 & 19,0 & 63,3 & 283,2 & 100 & 60,5 \\
\hline 2004 & 224,5 & 70,8 & 38,9 & 92,5 & 29,2 & 16,0 & 68,6 & 317,0 & 100 & 54,9 \\
\hline 2005 & 244,8 & 73,7 & 36,3 & 87,2 & 26,3 & 12,9 & 64,6 & 331,9 & 100 & 49,3 \\
\hline 2006 & 251,5 & 72,8 & 31,9 & 94,0 & 27,2 & 11,9 & 66,6 & 345,5 & 100 & 43,8 \\
\hline 2007 & 255,3 & 76,5 & 29,0 & 78,6 & 23,5 & 8,9 & 67,1 & 333,9 & 100 & 37,9 \\
\hline 2008 & 274,8 & 72,2 & 27,6 & 106,0 & 27,8 & 10,7 & 69,8 & 380,8 & 100 & 38,3 \\
\hline 2009 & 330,0 & 74,7 & 33,0 & 112,0 & 25,3 & 11,2 & 74,1 & 442,0 & 100 & 44,2 \\
\hline 2010 & 352,8 & 74,4 & 30,4 & 121,3 & 25,6 & 10,5 & 78,1 & 474,1 & 100 & 40,9 \\
\hline 2011 & 368,8 & 71,0 & 26,4 & 150,3 & 29,0 & 10,8 & 79,2 & 519,1 & 100 & 37,2 \\
\hline 2012 & 386,5 & 72,5 & 24,6 & 146,4 & 27,5 & 9,3 & 81,7 & 532,9 & 100 & 33,9 \\
\hline 2013 & 403,0 & 68,7 & 22,3 & 183,2 & 31,3 & 10,1 & 85,7 & 586,2 & 100 & 32,4 \\
\hline 2014 & 414,6 & 67,7 & 20,3 & 197,9 & 32,3 & 9,7 & 85,2 & 612,5 & 100 & 30,0 \\
\hline 2015 & 440,1 & 64,9 & 18,8 & 238,1 & 35,1 & 10,2 & 81,7 & 678,2 & 100 & 29,0 \\
\hline 2016 & 468,6 & 61,7 & 18,0 & 291,3 & 38,3 & 11,2 & 82,6 & 760,0 & 100 & 29,1 \\
\hline 2017 & 535,4 & 61,1 & 17,2 & 341,0 & 38,9 & 11,0 & 90,2 & 876,5 & 100 & 28,2 \\
\hline 2018 & 586,1 & 54,9 & 15,7 & 481,0 & 45,1 & 12,9 & 91,2 & 1067,1 & 100 & 28,7 \\
\hline 2019* & 712,8 & 56,5 & 17,9 & 547,9 & 43,5 & 13,7 & 95,3 & 1260,7 & 100 & 31,6 \\
\hline
\end{tabular}

Dış borç miktarındaki artış, özellikle esnek veya yönetimli dalgalanan döviz kuru rejimlerinin uygulandığı ekonomilerde birtakım olumsuzlukları da beraberinde getirebilmektedir. $\mathrm{Bu}$ olumsuzluklar; dış borçların fiyatları ya da nominal döviz kurunu etkilemesi sebebiyle özel 
yatırımların azalması, dış şoklara karşı kırılganlığın artması veya toplam kamu harcamaları içerisindeki borç servisi oranının artmasıyla borç ödemesinde kullanılacak döviz stoklarının erimesi şeklinde ortaya çıkabilmektedir (Beaugrand, Loko ve Mlachila, 2002). Türkiye'de kamu kesiminin dış borçlarındaki artışla birlikte, döviz cinsinden ya da dövize endeksli borcun payının da 2012 yılı sonrasında arttığ 1 ve 2019'da \%50'ye yaklaşttğı görülmektedir. Bu durumun ortaya çıkmasında, özellikle 2019 yılında iç borç stoku içerisindeki döviz cinsinden ve dövize endeksli borç oranının önemli ölçüde artarak \%10,4'e ulaşmasının da etkisi bulunmaktadır. Bütün bunlar borcun yapısının döviz kuruna karşı bir kırılganlık taşımasına neden olmakta, bu durum da ekonomiye ilişkin risk algısını negatif etkilemekte ve dış şoklara karşı hassasiyeti arttırmaktadır. Şekil 4'de gösterilen ve aynı zamanda Türk tahvillerine duyulan güvene ilişkin dolaylı bir veri sunan beş yıllık CDS primindeki değişimi gösteren grafiğe bakıldığında da, Türkiye’ye ilişkin uluslararası risk algısındaki olumsuz değişim net bir şekilde görülebilmektedir. Bir ülkenin ekonomik temellerinde değişiklik olmamasına ve bazı makroekonomik göstergelerdeki (kamu borç yükü gibi) pozitif görünüme rağmen, ülke riskinin artması gibi dış şoklar, çok kısa bir zaman içinde döviz kurunu yükseltebilmektedir. Diğer taraftan, kamu kesimi riskinin bankalara ve finansal olmayan kuruluşlara hızla yayılmasıyla, iç talep ve ekonomik büyüme olumsuz etkilenebilmektedir. Bu durum, kamu borç yükünü arttırmakta ve ortaya çıkan kısır döngünün yarattığı problemler artarak devam etmektedir (Özatay ve Sak, 2019).

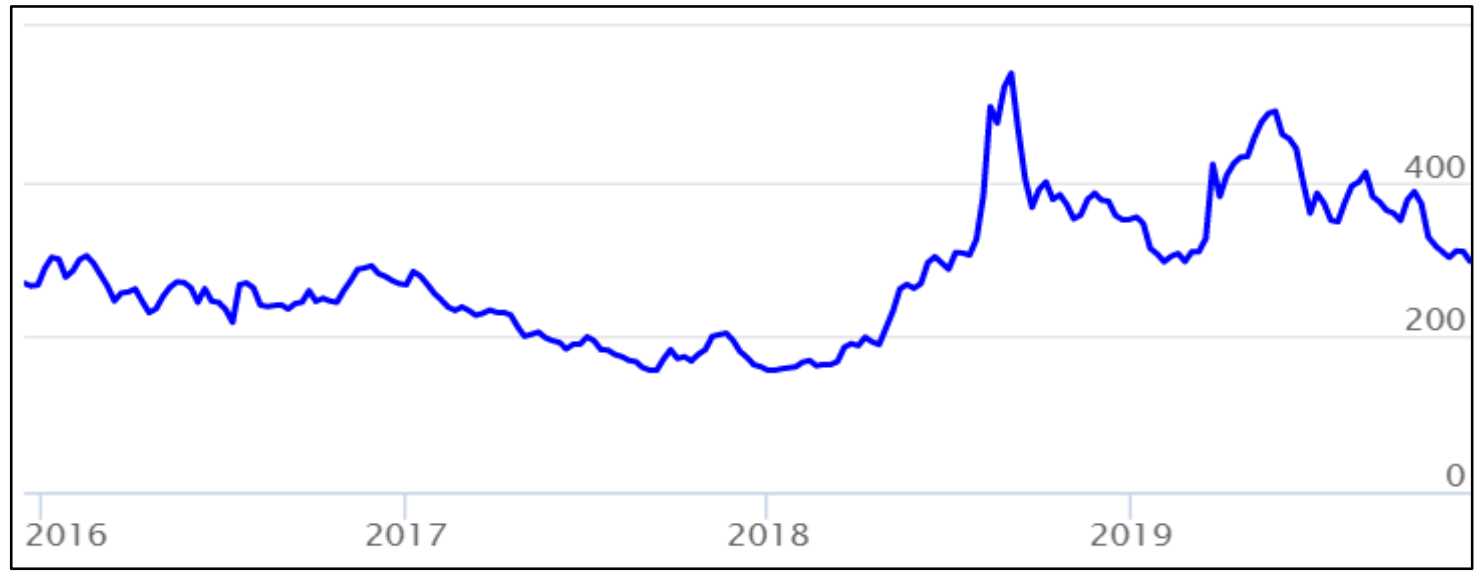

Şekil 4: Türkiye'nin 5 Yıllık CDS Primi (14.12.2015 - 09.12.2019)

Kaynak: http://www.worldgovernmentbonds.com/cds-historical-data/turkey/5-years/

Dış borç miktarındaki artışın Türkiye'nin uluslararası piyasalardaki risk görünümünü arttırıcı etki yapmasıyla birlikte, ABD Merkez Bankasının faiz artırımı kararları, özellikle 2013 yılı sonrasında yabancı sermaye çıkışlarına ve Türk Lirası'nın yabancı para birimleri karşısında değer kaybetmesine neden olmuştur. Dış faktörler ve jeopolitik riskler ile birlikte, Türkiye ekonomisinin kendi kırılganlıklarının da fiyatlandırılmasıyla, döviz kurunda önemli yükselişler ve dalgalanmalar meydana gelmiştir. Bu gelişmelerin devamında, 2018 yılında ciddi bir kur şokuyla karşı karşıya kalınmış ve döviz kuru zirve yapmış, Ağustos ayının sonunda Amerikan 
Doları kuru 6,54 seviyesine kadar çıkmıştır. Küresel piyasalardaki olumsuz beklentilerin de etkisiyle, 2015/01 - 2019/12 döneminde Türk Lirası Amerikan Doları karşısında \%147,6 oranında değer kaybederek, diğer gelişmekte olan ülkelerden negatif bir biçimde ayrışmıştır.

Temel piyasa göstergelerindeki bozulmalar ve Merkez Bankası'nın net döviz rezervlerindeki düşüşle birlikte, kamu kesiminin döviz cinsinden borç miktarındaki artış, uluslararası piyasalarda Türkiye ekonomisine ilişkin güveni azaltmıştır. Bu da döviz kurlarında sert yükselişleri beraberinde getirmiştir. Cari işlemler dengesi açısından bakıldığında sürekli olarak döviz açık pozisyonuna sahip olan ve kamu harcamalarını ulusal parayla finanse ederken borçlarını büyük oranda yabancı parayla ödeyen Türkiye gibi ülkelerde, bu durum büyük bir risk oluşturmaktadır.

\section{Literatür Taraması}

Hem uygulamada hem de literatürde, gelişmekte olan ekonomilerde döviz kuru dalgalanmaları ya da döviz krizleri ile borç krizleri arasında güçlü bir bağlantı olduğuna dair kanıtlar bulunmaktadır. Uluslararası finansal kurumlar tarafindan sağlanan kurtarma paketleri olmasaydı, 1990'lı y1llarda Meksika, Güney Kore ve Tayland'ın, daha sonra ise 2000'li yılların başında Türkiye'nin para birimlerinde ortaya çıkan krizlerin, bu ülkelerin yükümlülüklerini yerine getirememesine ve derin bir borç krizine sürüklenmesine neden olacağı konusundaki görüşler oldukça yaygındır (Reinhart, 2002).

Konuyla ilgili literatüre bakıldığında; Türkiye üzerine doğrudan döviz kuru değişimleri ile kamu borcu arasındaki ilişkinin incelendiği bir çalışma bulunmamakla birlikte, geniş kapsamda döviz kuru ile mali değişkenler arasındaki ilişkilerin araştırıldığı çalışmalardan bazıları şunlardır:

Güler (2017), BRIC ülkeleri ve Türkiye için döviz kuru oynaklığının kamu borç stoku ve dış borç servisi üzerindeki etkisini, 2010-2012 yılları arasında Amerikan Doları kurundaki aylık ortalama değişimi uyarlanmış beklentiler doğrultusunda 2013-2016 dönemi için tahmin ederek incelemiştir. Çalışmada elde ettiği bulgular, dolar kurundaki artışın Brezilya, Rusya ve Türkiye'nin mali sürdürülebilirlik göstergeleri üzerinde önemli etkisinin olduğunu göstermektedir. İlgün, Dumrul ve Aysu (2014) çalışmalarında, 1994-2012 dönemi için Türkiye'de bütçe açıklarının reel döviz kuru üzerindeki etkilerini sınır testi kullanarak incelemişler, bütçe açığı ve finansman biçimlerinin incelenen dönemde reel döviz kuru üzerinde anlamlı etkisinin olduğu sonucuna ulaşmışlardır. Temür, Çetin, Eroğlu ve Eroğlu (2014) ise, 2000-2011 dönemi için Türkiye'nin kamu borç yükünün belirleyicilerini inceledikleri çalışmalarında, döviz kurunun kamu borcu üzerinde arttırıcı bir etkisinin olduğunu tespit etmişlerdir. Bir başka çalışmada Tanner ve Samake (2008); Türkiye, Brezilya ve Meksika için kamu borçlarının sürdürülebilirliğini VAR yaklaşımı ile incelemişlerdir. Elde ettikleri bulgular, 
Türkiye'de 2001 krizinden sonra döviz kurlarında ve faiz oranlarındaki oynaklığın kamu borç miktarını arttırdığını, yaşanan döviz kuru şoklarının borç sürdürülebilirliğini negatif etkilediğini göstermektedir. Özgen ve Güloğlu (2004) ise çalışmalarında, Türkiye'de iç borçlar ve seçilen makroekonomik değişkenler arasındaki ilişkileri, 1988-2003 dönemi verilerini kullanarak, VAR modelleri ile incelemişlerdir. Çalışmanın bulguları, iç borç stokundan döviz kuruna doğru tek yönlü bir nedensellik ilişkisi olduğunu göstermektedir. Diğer taraftan, etki-tepki analizi ve varyans ayrıştırma sonuçları, döviz kuru değişimlerinin iç borç artışı üzerinde önemli bir etkisinin olmadığına işaret etmektedir.

Diğer taraftan, çeşitli ülke örnekleri için kamu borçları ile döviz kuru ilişkisini inceleyen çalışmalar şu şekilde özetlenebilmektedir:

Yien, Abdullah ve Azam (2017), Malezya ekonomisinde, iç borç, diş borç, döviz kuru ve enflasyon arasındaki dinamik ilişkileri, Johansen eşbütünleşme yaklaşımı ve Granger nedensellik testi ile incelemişlerdir. Elde ettikleri bulgular; iç borç stokundan döviz kuruna doğru tek yönlü ve dış borç stoku ile döviz kuru arasında çift yönlü nedensellik ilişkisi olduğunu göstermektedir. Saheed, Sani ve Idakwoji (2015), Nijerya için kamu dış borcunun döviz kuru üzerindeki etkisini en küçük kareler yöntemiyle incelemişler, dış borç stoku ve dış borç servisinin döviz kuru dalgalanmalarını açıklamada istatistiksel olarak anlamlı olduğu sonucuna ulaşmışlardır. Carrera ve Vergara (2012) ise çalışmalarında, reel döviz kuru şoklarının kamu borçları üzerindeki etkisini seçilmiş ülkeler kapsamında incelemişlerdir. Sonuçlar, döviz cinsinden kamu borç oranın yüksek olması durumunda döviz kurundaki artışların borç sürdürülebilirliğini negatif etkilediğini göstermektedir. Papaioannou (2009) çalışmasında, kamu borç yönetiminde döviz kuru riskini Doğu Avrupa ülkeleri kapsamında incelemektedir. Çalışmada, gelişmekte olan ülkelerin, uluslararası piyasalarda ihraç ettikleri tahvillerin miktarının düşük olması ve iç borçlanma piyasalarının yeterince gelişmemiş olmasının kamu borç portföylerindeki kur riskini arttırdığ 1 ifade edilmektedir. Schonerwald da Silva ve Vernengo (2007); kamu borç dinamiklerini, döviz kuru ve faiz oranı değişkenleri kapsamında Latin Amerika ülkeleri için incelemişlerdir. Çalışmada, kamu borç stokunda döviz cinsinden borçların oranın fazla olduğu ve uluslararası borçlanma piyasalarında para birimleri güçlü olmayan ülkelerde, döviz kuru dinamiklerinin kamu borçlarını açıklamada önemli olduğu sonucuna ulaşmışlardır. Penalver ve Thwaites (2006), Brezilya için kamu borç stokunun belirleyicilerini VAR analizi ile incelemişler, döviz kuru değişkenini de modele açıklayıcı değişken olarak dahil etmiş̧lerdir. Elde ettikleri bulgular, borç yükünün döviz kuru hareketleri üzerinde etkili olduğunu ve reel döviz kurunu negatif etkilediğini göstermektedir. Sène (2004) çalışmasında, gelişmekte olan ülkelerin kamu dış borcu ile reel döviz kuru arasındaki ilişkiyi Obstfeld ve Rogoff (1995) modelinin bir uzantısını kullanarak incelemiş, borç stokundaki artışın uzun vadede denge döviz kurunun yükselmesine neden olduğunu 
göstermiştir. Tille (2003), döviz kuru hareketlerinin ABD’nin dış borçları üzerindeki etkisini incelediği çalışmasında, Amerikan Doları'ndaki değer artışının borç stoku artışı üzerinde önemli bir etkisinin olduğunu belirtmektedir. Azam (1997) ise, CFA Frangı bölgesi ülkelerinde kamu borcu ve döviz kuru arasındaki ilişkiyi incelemiş, borç sorununun ve uygulanan yanlış politikaların yaşanan devalüasyonların bir nedeni olduğunu tespit etmiştir.

\section{Uygulama: Veri, Yöntem ve Bulgular}

Çalışmanın analiz kısmında, Türkiye'de kamu borç stoku ile döviz kuru hareketleri arasındaki ilişki VAR modelleri yardımıyla incelenmiştir. Bu bağlamda, merkezi yönetim borç stokunun farklı bileşenleri ile döviz kuru arasındaki uzun dönemli ilişkilerin varlığı Johansen eşbütünleşme yaklaşımıyla analiz edilmiştir. Devamında vektör hata düzeltme (VEC) modelleri tahmin edilerek, değişkenler arasındaki kısa ve uzun dönem nedensellik ilişkileri VECM Granger nedensellik testi ile araştırılmıştır. Son olarak, değişkenler arasındaki dinamik ilişkiler ise VAR modeline dayalı etki-tepki ve varyans ayrıştırma analizleri ile incelenmiştir. 2002:01 - 2019:10 dönemine ilişkin aylık verilerin kullanıldığı çalışmada, reel döviz kuru verileri Türkiye Cumhuriyet Merkez Bankası (TCMB), borç stoku ile ilgili diğer değişkenlere ilişkin veriler ise T. C. Hazine ve Maliye Bakanlığı internet sitelerinden alınmıştır. Çalışma ile ilgili Trakya Üniversitesi Sosyal ve Beşeri Bilimler Araştırmaları Etik Kurulu'na 28.04.2020 tarihinde başvuru yapılmış, kurulun 06.05.2020 tarihli ve 03/22 sayılı kararı ile çalışmanın etik açıdan uygun olduğu belirtilmiştir. Döviz kuru değişkeni ile merkezi yönetim borç stoku ve diğer alt bileşenleri (iç borç stoku, dış borç stoku, Türk Lirası cinsinden borç stoku ve yabancı para cinsinden borç stoku) arasındaki ilişkiler farklı VAR modelleri ile ayrı ayrı analiz edilmiş, tüm değişkenlerin logaritmik formları modellere dahil edilmiştir. Bu doğrultuda, değişkenler arasındaki ilişkiler aşağıda yer alan tam logaritmik modeller yardımıyla gösterilmiştir:

$$
\begin{aligned}
& \ln R D K_{t}=\alpha_{1}+\beta_{1} \ln T B_{t}+\varepsilon_{1 t} \\
& \ln R D K_{t}=\alpha_{2}+\beta_{2} \ln I B_{t}+\varepsilon_{2 t} \\
& \ln R D K_{t}=\alpha_{3}+\beta_{3} \ln D B_{t}+\varepsilon_{3 t} \\
& \ln R D K_{t}=\alpha_{4}+\beta_{4} \ln T L B_{t}+\varepsilon_{4 t} \\
& \ln R D K_{t}=\alpha_{5}+\beta_{5} \ln Y P B_{t}+\varepsilon_{5 t}
\end{aligned}
$$

Yukarıdaki denklemlerde; $R D K_{t}$ TÜFE bazlı (2003=100) reel efektif döviz kurunu, $T B_{t}$ merkezi yönetim toplam borç stokunu, $I B_{t}$ merkezi yönetim iç borç stokunu, $D B_{t}$ merkezi yönetim diş borç stokunu, $T L B_{t}$ merkezi yönetim Türk Lirası cinsinden borç stokunu ve $Y P B_{t}$ merkezi yönetim yabancı para cinsinden borç stokunu ifade etmektedir.

$\mathrm{Bu}$ kapsamda, öncelikle değişkenlerin durağanlıkları birim kök testleriyle incelenerek, serilerin bütünleşme dereceleri belirlenmiştir. Nelson ve Plosseri (1982), tipik makroekonomik zaman serilerinin hemen hemen hepsinin bir birim kökü olduğunu, yani durağan olmadığını ileri 
sürmektedir. Bu doğrultuda, bir serideki birim köklerin varlığını test etmede kullanılan en yaygın yöntemlerden Augmented Dickey Fuller (ADF) ve Phillips-Perron (PP) birim kök testleri uygulanmış, sonuçlar Tablo 2'de gösterilmiştir.

Tablo 2: Birim Kök Test Sonuçları

\begin{tabular}{|c|c|c|c|c|c|c|}
\hline & \multicolumn{3}{|c|}{ ADF } & \multicolumn{3}{|c|}{$\mathbf{P P}$} \\
\hline & $\mathrm{N}$ & $\mathrm{C}$ & $\mathrm{C} / \mathrm{T}$ & $\mathrm{N}$ & $\bar{C}$ & $\mathrm{C} / \mathrm{T}$ \\
\hline $\ln R D K$ & $-0,64(2)$ & $-1,16(2)$ & $-1,94(2)$ & $-0,62(11)$ & $-1,13(9)$ & $-1,93(9)$ \\
\hline $\ln T B$ & $7,44(0)$ & $-0,27(0)$ & $-1,58(0)$ & $6,88(1)$ & $-0,29(1)$ & $-1,76(2)$ \\
\hline $\ln I B$ & $7,12(1)$ & $-3,16^{\mathrm{b}}(1)$ & $-4,95^{\mathrm{a}}(1)$ & $6,10(7)$ & $-1,48(6)$ & $-2,55(6)$ \\
\hline $\ln D B$ & $3,59(0)$ & $0,25(0)$ & $-1,08(0)$ & $3,46(1)$ & $0,20(1)$ & $-1,17(3)$ \\
\hline $\ln T L B$ & $1,91(6)$ & $-6,66^{a}(1)$ & $-7,12^{\mathrm{a}}(1)$ & $5,15(9)$ & $-4,40^{a}(7)$ & $-4,08^{a}(5)$ \\
\hline $\ln Y P B$ & $3,06(0)$ & $1,78(0)$ & $0,07(0)$ & $2,94(3)$ & $2,02(7)$ & $0,20(6)$ \\
\hline$\Delta \ln R D K$ & $-11,52^{a}(1)$ & $-11,51^{a}(1)$ & $-11,56^{\mathrm{a}}(1)$ & $-10,4^{\mathrm{a}}(12)$ & $-10,4^{a}(13)$ & $-10,6^{a}(14)$ \\
\hline$\triangle \ln T B$ & $-10,27^{\mathrm{a}}(0)$ & $-12,28^{a}(0)$ & $-12,25^{\mathrm{a}}(0)$ & $-10,72^{a}(6)$ & $-12,23^{a}(4)$ & $-12,20^{a}(4)$ \\
\hline$\Delta \ln I B$ & $-2,37^{b}(5)$ & $-12,69^{a}(0)$ & $-12,95^{\mathrm{a}}(0)$ & $-10,90^{\mathrm{a}}(8)$ & $-13,13^{a}(7)$ & $-13,13^{a}(6)$ \\
\hline$\triangle \ln D B$ & $-14,03^{a}(0)$ & $-14,63^{\mathrm{a}}(0)$ & $-14,72^{a}(0)$ & $-14,03^{\mathrm{a}}(0)$ & $-14,76^{a}(6)$ & $-15,00^{a}(8)$ \\
\hline$\triangle \ln T L B$ & $-2,24^{b}(5)$ & $-3,00^{\mathrm{b}}(5)$ & $-3,17^{c}(5)$ & $-8,52^{a}(7)$ & $-11,58^{a}(7)$ & $-12,56^{a}(7)$ \\
\hline$\triangle \ln Y P B$ & $-12,78^{\mathrm{a}}(0)$ & $-13,18^{\mathrm{a}}(0)$ & $-13,49^{a}(0)$ & $-12,78^{a}(2)$ & $-13,14^{a}(6)$ & $-13,5^{\mathrm{a}}(10)$ \\
\hline
\end{tabular}

Birim kök testleri sonuçlarına göre, modellerde yer alan bütün serilerin düzey değerlerinin durağan olmadıkları ve birinci farkları alındıktan sonra durağan hale geldikleri görülmektedir. Bu doğrultuda, birinci dereceden bütünleşik olan seriler arasındaki uzun dönemli ilişki Johansen Eşbütünleşme Testi ile araştırılmıştır. Johansen (1988) ile Stock ve Watson (1988) tarafından geliştirilen bu yöntemde, değişkenler arasındaki eşbütünleşmeyi sağlayan vektörlerin tahmini maksimum benzerlik yöntemi ile hesaplanmaktadır. Modelde yer alan bütün değişkenlerin bütünleşme derecelerinin eşit olması koşulu bulunan Johansen eşbütünleşme yaklaşımında, iz istatistiği ve maksimum özdeğer istatistiği hesaplanarak, eşbütünleşik vektör sayısını gösteren katsayılar matrisinin karakteristik kökleri belirlenmektedir. Buradan hareketle de değişkenler arasında uzun dönemli ilişki olup olmadığı ve eğer varsa eşbütünleşme vektörü tespit edilmektedir. Johansen eşbütünleşme prosedürü, durağan olmayan serilerin düzey değerleri ile farklarını içeren aşağıdaki gibi bir VAR modeli tahminine dayanmaktadır (Johansen ve Juselius, 1990):

$$
H_{1}: X_{t}=\Pi_{1} X_{t-1}+\Pi_{2} X_{t-2}+\cdots+\Pi_{k} X_{t-k}+\mu+\varepsilon_{t}
$$

Denklem (6)'da yer alan $X$ değişkenler vektörünü, $\Pi$ değişkenlerin katsayı matrisini ve uzun dönem ilişkisini, $\mu$ sabit terimler vektörünü, $\varepsilon_{t}$ ise sıfır ortalama ve sabit varyans özelliklerine sahip hata terimini göstermektedir. Bu modeldeki $\Pi$ katsayılar matrisinin rankından yola çıkarak değişkenler arasındaki uzun dönem ilişkisi araştırılmaktadır. Eşbütünleşik vektör sayısını gösteren katsayılar matrisinin rankı belirlenirken, maksimum olabilirlik istatistiklerine dayanan iz test istatistiği ve maksimum özdeğer test istatistiği hesaplanmakta, böylece $\Pi$ matrisinin karakteristik köklerinin sayısı tespit edilmektedir. İz istatistiği eşbütünleşme vektör 
sayısının (r) sıfıra eşit ya da sıfırdan küçük olma durumunu sıfıra eşit olma hipotezine karşı sınarken, maksimum özdeğer istatistiği ise $r$ sayıda eşbütünleşme vektörünün olma durumunu, r+1 sayıda eşbütünleşme vektörünün bulunduğunu ifade eden alternatif hipoteze karş1 sınamaktadır. Gecikme uzunluğuna oldukça duyarlı olan Johansen eşbütünleşme prosedüründe uygun gecikme uzunluğunun seçimi, tahmin edilen VAR modeli yardımıyla AIC veya SIC gibi bilgi kriterleri kullanılarak yapılmaktadır. Değişkenler arasında eşbütünleşme ilişkisinin olması durumunda ise hata düzeltme modeli tahmin edilerek, değişkenler arasındaki dinamik ilişkiler bu model yardımıyla incelenmektedir.

$\mathrm{Bu}$ doğrultuda, borç stoku değişkenlerinin her biri ile reel döviz kuru değişkeninin yer aldığ beş ayrı VAR modeli oluşturulmuş, gecikme uzunluğu ve Johansen eşbütünleşme testinde kullanılacak modelin seçimi Schwarz Bilgi Kriteri (SIC)'ne göre belirlenmiştir. Karar aşamasında, Johansen (1988) ile Johansen ve Juselius (1990) çalışmalarında sunulan kritik değerlerin, farklı asimptotik dağılımları da içerecek şekilde yeniden hesaplanmış ve genişletilmiş versiyonları olan Osterwald-Lenum (1992)'da yer alan kritik değerler kullanılmıştır. Johansen eşbütünleşme testi sonuçları Tablo 3'de sunulmuştur.

Tablo 3: Eşbütünleşme Testi Sonuçları

\begin{tabular}{|c|c|c|c|c|c|c|c|c|}
\hline & \multirow{2}{*}{$\begin{array}{c}\text { Model } \\
\text { (Gecikme } \\
\text { Uzunluğu) }\end{array}$} & \multirow[t]{2}{*}{$\begin{array}{c}\mathbf{H}_{0} \\
\text { Hipotezi }\end{array}$} & \multirow[t]{2}{*}{$\begin{array}{c}\dot{\mathbf{I} z} \\
\text { İstatistiği }\end{array}$} & \multicolumn{2}{|c|}{$\begin{array}{c}\text { Kritik } \\
\text { Değerler }\end{array}$} & \multirow{2}{*}{$\begin{array}{c}\text { Maksimum } \\
\text { Özdeğer } \\
\text { İstatistiği }\end{array}$} & \multicolumn{2}{|c|}{$\begin{array}{c}\text { Kritik } \\
\text { Değerler }\end{array}$} \\
\hline & & & & $\% 5$ & $\% 1$ & & $\% 5$ & $\% 1$ \\
\hline \multirow{2}{*}{$\begin{array}{l}\ln T B \\
\ln R D K\end{array}$} & \multirow{2}{*}{$\begin{array}{c}\text { Model } 2 \\
(1)\end{array}$} & $\mathrm{r}=0$ & 125,02 & 19,96 & 24,60 & 119,96 & 15,67 & 20,20 \\
\hline & & $\mathrm{r} \leq 1$ & 5,056 & 9,24 & 12,97 & 5,056 & 9,24 & 12,97 \\
\hline \multirow{2}{*}{$\begin{array}{l}\ln I B \\
\ln R D K\end{array}$} & \multirow{2}{*}{$\begin{array}{c}\text { Model } 2 \\
\text { (1) }\end{array}$} & $r=0$ & 99,43 & 19,96 & 24,60 & 95,54 & 15,67 & 20,20 \\
\hline & & $\mathrm{r} \leq 1$ & 4,886 & 9,24 & 12,97 & 4,886 & 9,24 & 12,97 \\
\hline \multirow{2}{*}{$\begin{array}{l}\ln D B \\
\ln R D K\end{array}$} & \multirow{2}{*}{$\begin{array}{l}\text { Model } 4 \\
\text { (1) }\end{array}$} & $\mathrm{r}=0$ & 49,46 & 25,32 & 30,45 & 46,32 & 18,96 & 23,65 \\
\hline & & $r \leq 1$ & 3,137 & 12,25 & 16,26 & 3,137 & 12,25 & 16,26 \\
\hline \multirow{2}{*}{$\begin{array}{l}\ln T L B \\
\ln R D K\end{array}$} & \multirow{2}{*}{$\begin{array}{c}\text { Model } 2 \\
\text { (1) }\end{array}$} & $r=0$ & 111,25 & 19,96 & 24,60 & 106,23 & 15,67 & 20,20 \\
\hline & & $\mathrm{r} \leq 1$ & 5,021 & 9,24 & 12,97 & 5,021 & 9,24 & 12,97 \\
\hline \multirow{2}{*}{$\begin{array}{l}\ln Y P B \\
\ln R D K\end{array}$} & \multirow{2}{*}{$\begin{array}{l}\text { Model } 5 \\
\text { (1) }\end{array}$} & $r=0$ & 39,99 & 18,17 & 23,46 & 39,98 & 16,87 & 21,47 \\
\hline & & $r \leq 1$ & 0,011 & 3,74 & 6,40 & 0,011 & 3,74 & 6,40 \\
\hline
\end{tabular}

Johansen eşbütünleşme testi bulgularına bakıldığında; oluşturulan beş ayrı modelin hepsinde hem iz istatistiği hem de maksimum özdeğer istatistiğine göre, $r=0$ için test istatistiklerinin kritik değerlerden büyük olduğu görülmektedir. Bu durumda, değişkenler arasında eşbütünleşme ilişkisi olmadığını $(r=0)$ ifade eden sıfır hipotezi reddedilmektedir. Diğer taraftan, değişkenler arasında en az bir eşbütünleşme vektörü olduğunu $(\mathrm{r} \leq 1)$ ifade eden hipotez bütün modellerde reddedilememektedir. Dolayısıyla, $\operatorname{lnRDK}$ değişkeni ile borç stoku değişkenlerinin tamamı arasında uzun dönemli ilişki olduğu sonucu ortaya çıkmaktadır.

Engle ve Granger (1987)'e göre; değişkenler arasında eşbütünleşme ilişkisinin olması durumunda, dinamik ilişkilerin hata düzeltme modeli ile tahmin edilmesi gerekmektedir. Bu doğrultuda, analize vektör hata düzeltme (Vector Error Correction - VEC) modelleri ile devam 
edilmiştir. Johansen eşbütünleşme testinde kullanılan gecikme uzunlukları ile oluşturulan vektör hata düzeltme modelleri tahmin edilmiş, bu modeller üzerinden gerçekleştirilen Granger Nedensellik Testi, etki-tepki fonksiyonları ve varyans ayrıştırma analizi sonuçları yorumlanmıştır. İlk olarak, değişkenler arasındaki muhtemel nedensellik ilişkilerini ve ilişkinin yönünü ortaya koyan Granger Nedensellik Testi uygulanmıştır. Vektör hata düzeltme modeline dayalı Granger nedensellik testinde, uzun dönem ilişkisinden elde edilen hata düzeltme terimi $\left(e c t_{t-1}\right)$ VAR modeline bir değişken olarak ilave edilmektedir. Buna göre; reel döviz kuru ile kamu borç stokunun bileşenleri arasındaki nedensellik ilişkisinin araştırılacağı modeller, her bir değişken grubu için ayrı ayrı olmak üzere aşağıdaki gibi oluşturulmuştur:

$$
\begin{aligned}
& (1-L)\left[\begin{array}{c}
\ln R D K_{t} \\
\ln T B_{t}
\end{array}\right]=\left[\begin{array}{l}
a_{1} \\
a_{2}
\end{array}\right]+\sum_{i=1}^{p}(1-L)\left[\begin{array}{ll}
b_{11 i} & b_{12 i} \\
b_{21 i} & b_{22 i}
\end{array}\right]\left[\begin{array}{c}
\ln R D K_{t-1} \\
\ln T B_{t-1}
\end{array}\right]+\left[\begin{array}{l}
\alpha \\
\beta
\end{array}\right] e c t_{t-1}+\left[\begin{array}{l}
\varepsilon_{1 t} \\
\varepsilon_{2 t}
\end{array}\right] \\
& (1-L)\left[\begin{array}{c}
\ln R D K_{t} \\
\ln I B_{t}
\end{array}\right]=\left[\begin{array}{l}
a_{1} \\
a_{2}
\end{array}\right]+\sum_{i=1}^{p}(1-L)\left[\begin{array}{ll}
b_{11 i} & b_{12 i} \\
b_{21 i} & b_{22 i}
\end{array}\right]\left[\begin{array}{c}
\ln R D K_{t-1} \\
\ln I B_{t-1}
\end{array}\right]+\left[\begin{array}{l}
\alpha \\
\beta
\end{array}\right] e c t_{t-1}+\left[\begin{array}{l}
\varepsilon_{1 t} \\
\varepsilon_{2 t}
\end{array}\right] \\
& (1-L)\left[\begin{array}{c}
\ln R D K_{t} \\
\ln D B_{t}
\end{array}\right]=\left[\begin{array}{l}
a_{1} \\
a_{2}
\end{array}\right]+\sum_{i=1}^{p}(1-L)\left[\begin{array}{ll}
b_{11 i} & b_{12 i} \\
b_{21 i} & b_{22 i}
\end{array}\right]\left[\begin{array}{c}
\ln R D K_{t-1} \\
\ln D B_{t-1}
\end{array}\right]+\left[\begin{array}{l}
\alpha \\
\beta
\end{array}\right] e c t_{t-1}+\left[\begin{array}{l}
\varepsilon_{1 t} \\
\varepsilon_{2 t}
\end{array}\right] \\
& (1-L)\left[\begin{array}{c}
\ln R D K_{t} \\
\ln T L B_{t}
\end{array}\right]=\left[\begin{array}{l}
a_{1} \\
a_{2}
\end{array}\right]+\sum_{i=1}^{p}(1-L)\left[\begin{array}{ll}
b_{11 i} & b_{12 i} \\
b_{21 i} & b_{22 i}
\end{array}\right]\left[\begin{array}{l}
\ln R D K_{t-1} \\
\ln T L B_{t-1}
\end{array}\right]+\left[\begin{array}{l}
\alpha \\
\beta
\end{array}\right] e c t_{t-1}+\left[\begin{array}{l}
\varepsilon_{1 t} \\
\varepsilon_{2 t}
\end{array}\right] \\
& (1-L)\left[\begin{array}{c}
\ln R D K_{t} \\
\ln Y P B_{t}
\end{array}\right]=\left[\begin{array}{l}
a_{1} \\
a_{2}
\end{array}\right]+\sum_{i=1}^{p}(1-L)\left[\begin{array}{ll}
b_{11 i} & b_{12 i} \\
b_{21 i} & b_{22 i}
\end{array}\right]\left[\begin{array}{l}
\ln R D K_{t-1} \\
\ln Y P B_{t-1}
\end{array}\right]+\left[\begin{array}{l}
\alpha \\
\beta
\end{array}\right] e c t_{t-1}+\left[\begin{array}{l}
\varepsilon_{1 t} \\
\varepsilon_{2 t}
\end{array}\right]
\end{aligned}
$$

Yukarıda yer alan denklemlerde, $e t_{t-1}$ uzun dönem ilişkisinin tahmininden elde edilen gecikmeli hata düzeltme terimini, (1-L) ise fark operatörünü ifade etmektedir. Vektör hata düzeltme modeli, değişkenler arasındaki kısa dönem ve uzun dönem nedenselliklerinin birbirinden ayırt edilmesini sağlayan bir yöntemdir. Gecikmeli hata düzeltme teriminin katsayılarına ait t-istatistiğinin anlamlı olması, uzun dönemde nedensellik ilişkisinin varlığına işaret etmektedir. Bununla birlikte, bağımsız değişkenlerin birinci farklarının katsayılarına ait Fistatistiğinin anlamlı olması da kısa dönemde nedensellik ilişkisinin bulunduğunu göstermektedir. Vektör hata düzeltme modeline dayalı Granger nedensellik testi sonuçları Tablo 4'de gösterilmiştir.

VECM Granger nedensellik testi sonuçlarından istatistiksel olarak anlamlı olanlara bakıldığında; uzun dönemde, reel döviz kurundan $(\ln R D K)$ sırasıyla toplam borç stoku $(\ln T B)$, iç borç stoku $(\ln I B)$ ve Türk Lirası cinsinden borç stokuna $(\ln T L B)$ doğru bir nedensellik ilişkisi olduğu görülmüş, diğer taraftan toplam borç stoku $(\ln T B)$, dış borç stoku $(\ln D B)$ ve yabancı para cinsinden borç stoku $(\ln Y P B)$ değişkenlerinden reel döviz kuruna doğru işleyen bir nedensellik ilişkisi tespit edilmiştir. Kısa dönemde ise, toplam borç stoku, dış borç stoku ve yabancı para 
Umut AKDUĞAN

Türkiye'de Döviz Kuru Hareketleri ve Kamu Borcu İlişkisi

cinsinden borç stoku değişkenlerinden reel döviz kuruna doğru tek yönlü bir nedensellik ilişkisi olduğu, ayrıca reel döviz kurundan Türk Lirası cinsinden borç stokuna doğru tek yönlü bir nedensellik ilişkisi olduğu belirlenmiştir.

Tablo 4: VECM Granger Nedensellik Testi Sonuçları

\begin{tabular}{|c|c|c|c|c|}
\hline \multirow{3}{*}{$\begin{array}{l}\text { Bağımlı } \\
\text { Değiş̧ken }\end{array}$} & \multirow{2}{*}{\multicolumn{2}{|c|}{$\begin{array}{l}\text { Kısa Dönem } \\
(F \text {-istatistiği) }\end{array}$}} & \multicolumn{2}{|c|}{ Uzun Dönem } \\
\hline & & & \multirow[t]{2}{*}{$E C T(-1)$} & \multirow[t]{2}{*}{$t$-istatistiğ } \\
\hline & $\Delta \ln R D K$ & $\Delta \ln T B$ & & \\
\hline$\Delta \ln R D K$ & - & $56,81^{\mathrm{a}}(0,0000)$ & $-0,0121^{\mathrm{a}}$ & $-5,1489$ \\
\hline \multirow[t]{2}{*}{$\Delta \ln T B$} & $1,447(0,2289)$ & - & $-0,0068^{\mathrm{a}}$ & $-4,6986$ \\
\hline & $\Delta \ln R D K$ & $\Delta \ln I B$ & & \\
\hline$\Delta \ln R D K$ & - & $0,899(0,3428)$ & $-0,0044$ & $-1,2309$ \\
\hline \multirow[t]{2}{*}{$\Delta \ln I B$} & $2,204(0,1376)$ & - & $-0,0113^{\mathrm{a}}$ & $-10,475$ \\
\hline & $\Delta \ln R D K$ & $\Delta \ln D B$ & & \\
\hline$\Delta \ln R D K$ & - & $44,75^{\mathrm{a}}(0,0000)$ & $-0,1220^{\mathrm{a}}$ & $-4,9817$ \\
\hline \multirow[t]{2}{*}{$\Delta \ln D B$} & $0,541(0,4621)$ & - & 0,0303 & 0,8168 \\
\hline & $\Delta \ln R D K$ & $\triangle \ln T L B$ & & \\
\hline$\Delta \ln R D K$ & - & $0,361(0,5481)$ & 0,0002 & 0,0461 \\
\hline \multirow[t]{2}{*}{$\triangle \ln T L B$} & $4,751^{\mathrm{b}}(0,0293)$ & - & $-0,0132^{\mathrm{a}}$ & $-11,656$ \\
\hline & $\triangle \ln R D K$ & $\triangle \ln Y P B$ & & \\
\hline$\Delta \ln R D K$ & - & $55,87^{\mathrm{a}}(0,0000)$ & $-0,0539^{a}$ & $-4,8012$ \\
\hline$\triangle \ln Y P B$ & $1,471(0,2250)$ & - & 0,0124 & 0,7500 \\
\hline
\end{tabular}

Kısa ve uzun dönem nedensellik sonuçlarına bakıldığında, dış borçlardan ve döviz cinsinden borç stokundan döviz kuruna doğru işleyen anlamlı bir ilişki olduğu görülmektedir. Bu bulgu; Saheed, Sani ve Idakwoji (2015), Penalver ve Thwaites (2006), Sène (2004) ve Azam (1997) çalışmalarında farklı ülkeler için elde edilen sonuçlarla büyük oranda örtüşmektedir. Diğer taraftan; reel döviz kurundan toplam borç, iç borç ve TL cinsinden borç stokuna doğru tespit edilen nedensellik ilişkisinin ise, Carrera ve Vergara (2012), Schonerwald da Silva ve Vernengo (2007) ile Tille (2003) çalışmalarıyla uyumlu olduğu görülmektedir.

Son olarak, değişkenler arasındaki dinamik ilişkileri incelemek için, VAR modellerine dayalı etki-tepki ve varyans ayrıştırma analizleri uygulanmış, bunların sonuçları çalışmanın Ekler kısmında sunulmuştur. Ek 1'de sunulan varyans ayrıştırma sonuçları şu şekilde özetlenebilmektedir:

- Reel döviz kurundaki değişimlerde, kamu kesimi toplam borç stoku $(\ln T B)$, dış borç stoku $(\ln D B)$ ve yabancı para cinsinden toplam borç stoku $(\ln Y P B)$ değişkenlerinin etkisi oldukça yüksektir. İncelenen periyodun son dönemine bakıldığında; $\ln R D K$ değişkeninde meydana gelen değişimlerde, $\ln T B$ 'nin etkisi \%80,6, $\ln D B$ 'nin etkisi \%92,7 ve $\ln Y P B$ 'nin etkisi \%89,4 olarak hesaplanmıştır.

- Kamu iç borç stoku $(\ln I B)$ ve Türk Lirası cinsinden toplam borç stokunda $(\ln T L B)$ meydana gelen değişimlerde ise reel döviz kurunun $(\ln R D K)$ önemli bir etkiye sahip olduğu sonucuna ulaşılmıştır. $\ln R D K$ 'nın $\ln I B$ 'ye etkisinin başlangıçta düşük olduğu, sonradan artarak 
\%37,5'a kadar çıktığı, $\operatorname{lnRDK}$ 'nın $\ln T L B$ üzerindeki etkisinin de başlangıçta düşük olduğu ve sonradan artarak \%40,2 düzeyine çıktı̆̆ görülmektedir.

Diğer taraftan, Ek 2'de yer alan etki-tepki fonksiyonlarına bakıldığında aşağıdaki bulgulara ulaşılabilmektedir:

- Reel döviz kuru $(\ln R D K)$ değişkeninin, kamu kesimi toplam borç stoku $(\ln T B)$, diş borç stoku $(\ln D B)$ ve yabancı para cinsinden toplam borç stoku $(\ln Y P B)$ değişkenlerindeki bir şoka verdiği tepkilerin anlamlı ve negatif olduğu, ayrıca söz konusu tepkilerin, kısa dönemde ortaya çıktığı görülmektedir.

- Kamu iç borç stoku $(\ln I B)$ ve Türk Lirası cinsinden toplam borç stoku $(\ln T L B)$ değişkenlerinin, reel döviz kurundaki bir şoka verdikleri tepkinin anlamlı ve negatif olduğu, ayrıca söz konusu tepkilerin şiddetinin başlangıçta düşük olup zaman içerisinde arttığ 1 görülmektedir.

\section{Sonuç}

Türk Lirası'nda yüksek oranlı devalüasyonun gerçekleştiği ve devamında döviz kuru rejimi değişikliğine kadar varan 2001 ekonomik krizi sonrasında, Türkiye'de döviz kurlarında ciddi dalgalanmaların yaşandığı ve ekonominin birçok kez kur şokuyla karşı karşıya kaldığ bilinmektedir. Bu sebeple; kamu borç dinamiklerinin ve kamu borcunun belirleyicilerinin çeşitli değişkenler kapsamında araştıııldığı diğer çalışmaların aksine, bu çalışma, yalnızca kamu borcu ile döviz kuru değişimleri arasındaki ilişkiye odaklanmaktadır. Temelde; Türkiye'de 2001 krizi sonrası dönemde, kamu borcu ile döviz kuru arasındaki ilişkinin yönünün belirlenmesi amaçlanmıştır. Bu bağlamda, merkezi yönetim borç stoku bileşenleri ile döviz kuru arasındaki uzun dönemli ilişkiler Johansen eşbütünleşme yaklaşımıyla analiz edilmiş, devamında vektör hata düzeltme (VEC) modelleri tahmin edilerek, değişkenler arasındaki kısa ve uzun dönem nedensellik ilişkileri VECM Granger nedensellik testi ile araştırılmıştır. Son olarak, değişkenler arasındaki dinamik ilişkiler ise VAR modeline dayalı etki-tepki ve varyans ayrıştırma analizleri ile incelenmiştir. Bu analiz sürecinden elde edilen bulgular genel olarak özetlendiğinde, toplam borç stoku, dış borç stoku ve döviz cinsinden toplam borç stokunun reel döviz kuru değişkeni üzerinde anlamlı etkisinin olduğu, diğer taraftan reel döviz kuru değişimlerinin iç borç stoku ve Türk Lirası cinsinden toplam borç stoku üzerinde etkili olduğu göze çarpmaktadır.

Elde edilen sonuçlar, kamu diş borç stoku ve döviz cinsinden borç stokundaki artışın döviz kuru üzerinde yukarı yönlü baskı yaptığını göstermektedir. Son dönemde, dış borç oranının kamu borç stoku içinde \%45 seviyesine kadar çıktığ 1 ve toplam kamu borç stokunun neredeyse yarısını döviz cinsi/dövize endeksli borçların oluşturduğu göz önünde bulundurulduğunda, toplam kamu borç stokundaki artışın döviz kurunu arttırıcı etki yapması da beklenen bir sonuçtur. 
Türkiye'de son yıllarda döviz kurlarında meydana gelen aşırı oynaklığa sebep olan pek çok faktör bulunmakla birlikte, söz konusu nedenlerin başında artan risk düzeyi gelmektedir. Risk derecesine ilişkin bir gösterge olan CDS primine bakıldığında Türkiye, diğer gelişen ülkelerden net bir şekilde negatif ayrışmaktadır. Bölgede yaşanan olumsuz gelişmelerle birlikte, Merkez Bankası tarafından alınan kararların yeterince karşılık bulamaması, yükselen enflasyon, kredi derecelendirme kuruluşlarının değerlendirmeleri ve yapısal reformların gerçekleşememesi gibi etkenler Türkiye'nin risklerini artırmış, bu da döviz kurlarında yükselişlere ve oynaklığa neden olmuştur. Çalışmanın sonuçları, kur artışına neden olan risk görünümünü negatif etkileyen faktörlerden birisinin de, kamu borç stokunun miktarındaki ve yapısındaki değişimler olduğunu göstermektedir. Yabancı para cinsinden kamu borcu ve dış borç miktarındaki artışın, yabancı yatırımcılar nezdinde temerrüt riski algısını tetiklediği ve ekonomiye ilişkin güveni azalttığı, bunun da yabancı sermaye (özellikle kısa vadeli portföy yatırımları) çıkışına neden olarak döviz talebini artırdığı anlaşılmaktadır. Dolayısıyla, kamu borcundaki değişimin döviz kuru üzerindeki etkisinin, dolaylı bir şekilde ortaya çıktığı tahmin edilmektedir.

Çalışmada elde edilen bir diğer anlamlı bulgu ise; döviz kurundaki yukarı yönlü hareketin, kamu iç borç stoku ve Türk Lirası cinsinden toplam borç stoku üzerindeki arttırıcı etkisidir. Döviz kurlarındaki artışla birlikte, yabancı para cinsinden borçlanmanın maliyeti arttığından, Türk Lirası ile borçlanmaya nispeten düşük reel faiz ödemek daha cazip hale gelmiş, bu da iç piyasalardan ve yerli para cinsinden borçlanma miktarını artırmıştır.

Çalışmanın bulguları, Türkiye'de kur oynaklığını arttıran faktörlerden biri olan iktisat politikası ve kamu borç yönetimine ilişkin risk algısının değişmesinde, kamu borç yükünün ve borç yapısının önemine işaret etmektedir. 2001 krizinden sonraki süreçte, Türkiye'nin kamu borç stoku/GSYH oranını \%70'lerden \%30'lara kadar düşüren maliye politikaları uygulamalarıyla sağladığı mali disiplin oldukça değerlidir. Ancak, son dönemde iç talebi arttırmaya yönelik olarak gerçekleştirilen politika önlemleri, dış piyasalarda mali disiplinden uzaklaşılmaya başlandığ izlenimi vermektedir. Ekonomik büyümeyi hızlandıracak (ya da ekonomik daralmanın şiddetini düşürecek) genişletici maliye politikasının uygulanmasında, kamu borçlanmasının ülkeye ilişkin risk algılamasını azaltacak şekilde yönetilmesinin, döviz kuru istikrarına da katkı sağlayacağı tahmin edilmektedir. Bir başka deyişle; kamu borcunun döviz-yerli para bileşiminde döviz oranının artması ve borç yükünün yükselmesi durumunda, maruz kaldığı diğer dış risklerle birlikte Türkiye ekonomisinin daha kırılgan hale gelmesi ve yeni kur şoklarının yaşanması ihtimali de artacaktır. 


\section{Kaynakça}

Azam, J. P. (1997). Public Debt and The Exchange Rate in The CFA Franc Zone. Journal of African Economies, 6(1), 54-84.

Beaugrand, P., Loko, B. ve Mlachila, M. (2002). The Choice Between External and Domestic Debt in Financing Budget Deficits: The Case of Central and West African Countries. IMF Working Paper, No. 02-79, 1-29.

Carrera, C. M. ve Vergara, R. (2012). Fiscal Sustainability: The Impact of Real Exchange Rate Shocks on Debt Valuation, Interest Rates and GDP Growth. World Development, 40(9), 1762-1783.

Eğilmez, M. (2012). İkiz Açık, Üçüz Açık. http://www.mahfiegilmez.com/2012/10/ikiz-ackucuz-ack.html (17.09.2019)

Eichengreen, B. ve Hausmann, R. (1999). Exchange Rate and Financial Fragility. NBER Working Paper, No. 7418, 1-54.

Engle, R. F. ve Granger, C. W. (1987). Co-integration and Error Correction: Representation, Estimation, and Testing. Econometrica, 55(2), 251-276.

Güler, H. (2017). Kur Baskısı Altında Kurallı Maliye Politikalarının Sürdürülebilirliği. Çukurova Üniversitesi Sosyal Bilimler Enstitüsü Dergisi, 26(2), 99-116.

Güngen, A. R. (2015). Türkiye'de Kamu Borcunun Yönetimi: 2001 Krizi Sonrası Bulgular Ve 2009 Çöküşü Sonrası Stratejiler. Praksis, 38, 129-153.

Hausmann, R. ve Panizza, U. (2003), On The Determinants of Original Sin: An Empirical Investigation. Journal of International Money and Finance, 22, 957-990.

İlgün, M. F., Dumrul, C. ve Aysu, A. (2014). Bütçe Açıklarının Reel Döviz Kuru Üzerindeki Etkileri: Türk Ekonomisi Üzerine Bir Uygulama. Uluslararası Yönetim İktisat ve İşletme Dergisi, 10(23), 13-30.

Johansen, S. (1988). Statistical Analysis of Cointegration Vectors. Journal of Economic Dynamics and Control. 12(2-3), 231-254.

Johansen, S. ve Juselius, K. (1990). Maximum Likelihood Estimation and Inference on Cointegration-With Applications to The Demand for Money. Oxford Bulletin of Economics and statistics, 52(2), 169-210.

Krugman, P. (1988). Financing vs. Forgiving A Debt Overhang, NBER Working Paper, No. 2486, $1-32$.

Margolin, D. (2007). Financial Stability and Local Currency Bond Markets. Committee on the Global Financial System Papers, 28, 1-142.

Nart, E. Ç. (2015). Dış Borç Yönetimi Açısından Finansal Kriz Riski. Dokuz Eylül Üniversitesi İktisadi İdari Bilimler Fakültesi Dergisi, 30(2), 71-85. 
Nelson, C. R. ve Plosseri C. R. (1982), Trends and Random Walks in Macroeconmic Time Series: Some Evidence and İmplications, Journal of Monetary Economics, 10(2), 139-162.

Neven, D. ve Wyplosz, C. (1999). Relative Prices, Trade and Restructuring in European Industry. Oxford University Press. (Ed. M. Dewtripont, A. Sapir ve K. Sekkat), Trade and jobs in Europe: Much ado about nothing? (s. 33-49).

Obstfeld, M. ve Rogoff, K. (1995). Exchange Rate Dynamics Redux. Journal of Political Economy, 103(3), 624-660.

Osterwald-Lenum, M. (1992). A Note With Quantiles of The Asymptotic Distribution of The Maximum Likelihood Cointegration Rank Test Statistics. Oxford Bulletin of Economics and Statistics, 54(3), 461-472.

Özatay, F. ve Sak, G. (2019). Maliye Politikasında Manevra Alanı Var Mı? Ekonominin Seyir Defteri, TEPAV, 1-16.

Özgen, F. B. ve Güloğlu, B. (2004). Türkiye'de İç Borçların İktisadi Etkilerinin VAR Tekniğiyle Analizi. ODTÜ Gelişme Dergisi, 31(Haziran). 93-114.

Papaioannou, M. G. (2009). Exchange Rate Risk Measurement and Management: Issues And Approaches for Public Debt Managers. South-Eastern Europe Journal of Economics, 1, 7-34.

Penalver, A. ve Thwaites, G. (2006). Fiscal Rules for Debt Sustainability in Emerging Markets: The Impact of Volatility and Default Risk. Bank of England Working Paper, No. 307, 125 .

Reinhart, C. M. (2002). Default, Currency Crises, and Sovereign Credit Ratings. The World Bank Economic Review, 16(2), 151-170.

Saheed, Z. S., Sani, I. E. ve Idakwoji, B. O. (2015). Impact of Public External Debt on Exchange Rate in Nigeria. European Journal of Business and Management, 7(21), 51-57.

Schonerwald da Silva, C. E. ve Vernengo, M. (2007). Foreign Exchange, Interest and The Dynamics of Public Debt in Latin America. Department of Economics Working Paper Series, No. 2007-02, The University of Utah, 1-20.

Sène, B. (2004). Impact Du Fardeau Virtuel De La Dette Sur Le Taux De Change Réel D'équilibre Des Pays En Développement: Un Modèle Théorique. EURISCO, No. 200417, Université Paris Dauphine.

Stock, J. H. ve Watson, M. W. (1988). Testing For Common Trends. Journal of the American Statistical Association. 83(404). 1097-1107.

Tanner, E. ve Samake, I. (2008). Probabilistic Sustainability of Public Debt: A Vector Autoregression Approach for Brazil, Mexico, and Turkey. IMF Staff Papers, 55(1), 149182. 
T. C. Hazine ve Maliye Bakanlığı, Merkezi Yönetim Borç İstatistikleri, https://www.hmb.gov.tr /kamu-finansmani-istatistikleri (24.11.2019)

Temür, Y., Çetin, A., Eroğlu, N. ve Eroğlu, İ. (2014). Maastricht Kriterleri Çerçevesinde Türkiye'nin Kamu Borç Yükü Üzerine Ampirik Bir Çalışma. Marmara Üniversitesi İktisadi ve İdari Bilimler Dergisi, 36(1), 229-243.

Tille, C. (2003). The Impact of Exchange Rate Movements on US Foreign Debt. Federal Reserve Bank of New York - Current Issues in Economics and Finance, 9(1), 1-7.

Ulusoy, A. ve Kara, D. (2017). Kamu Borç Yönetiminin Maliye ve Para Politikası İle Uyum Sorunu: Türkiye Pratiği. Maliye Araştırmaları Dergisi, 3(1), 29-38.

Uzunoğlu, S. (2005). Döviz Kuru: Kamu Borç Stoku ve Finansal Kesime Etkisi. Finans-Politik \& Ekonomik Yorumlar, 42(498), 8-14.

World Government Bonds, http://www.worldgovernmentbonds.com/cds-historical-data/turkey/ 5-years/ (26.11.2019)

Yavuz, H. H. (2009), Kamu Borç Yönetiminde Yabancı Para Cinsinden Borçlanmanın Etkileri: Türkiye Örneği, Maliye Dergisi, 157, 277-292.

Yien, L. C., Abdullah, H., ve Azam, M. (2017). Granger Causality Analysis Between Inflation, Debt And Exchange Rate: Evidence From Malaysia. International Journal of Academic Research in Accounting, Finance and Management Sciences, 7(1), 189-196. 


\section{Ekler}

EK 1: Varyans Ayrıştırma Analizi Sonuçları

\begin{tabular}{|c|c|c|c|c|c|c|c|c|c|c|c|c|}
\hline & \multicolumn{4}{|c|}{ Toplam Borç Stoku Modeli } & \multicolumn{4}{|c|}{ İç Borç Stoku Modeli } & \multicolumn{4}{|c|}{ Diş Borç Stoku Modeli } \\
\hline & \multicolumn{2}{|c|}{$\ln T B$} & \multicolumn{2}{|c|}{$\ln R D K$} & \multicolumn{2}{|c|}{$\ln I B$} & \multicolumn{2}{|c|}{$\ln R D K$} & \multicolumn{2}{|c|}{$\ln D B$} & \multicolumn{2}{|c|}{$\ln R D K$} \\
\hline & $\ln T B$ & $\operatorname{lnRDK}$ & $\ln T B$ & $\ln R D K$ & $\ln I B$ & $\ln R D K$ & $\ln I B$ & $\ln R D K$ & $\ln D B$ & $\ln R D K$ & $\ln D B$ & $\ln R D K$ \\
\hline 1 & 100 & 0,00 & 48,3 & 51,6 & 100 & 0,00 & 2,10 & 97,8 & 100 & 0,00 & 62,4 & 37,5 \\
\hline 2 & 99,9 & 0,02 & 70,0 & 29,9 & 98,1 & 1,89 & 2,95 & 97,0 & 99,8 & 0,15 & 80,1 & 19,8 \\
\hline 3 & 99,9 & 0,01 & 75,3 & 24,6 & 94,6 & 5,35 & 3,38 & 96,6 & 99,6 & 0,30 & 85,1 & 14,8 \\
\hline 4 & 99,9 & 0,06 & 77,4 & 22,5 & 90,3 & 9,65 & 3,62 & 96,3 & 99,5 & 0,41 & 87,6 & 12,3 \\
\hline 5 & 99,8 & 0,17 & 78,5 & 21,4 & 85,5 & 14,4 & 3,77 & 96,2 & 99,4 & 0,50 & 89,1 & 10,8 \\
\hline 6 & 99,6 & 0,32 & 79,2 & 20,7 & 80,6 & 19,3 & 3,87 & 96,1 & 99,4 & 0,58 & 90,3 & 9,69 \\
\hline 7 & 99,4 & 0,51 & 79,7 & 20,2 & 75,8 & 24,1 & 3,95 & 96,0 & 99,3 & 0,65 & 91,1 & 8,86 \\
\hline 8 & 99,2 & 0,72 & 80,1 & 19,8 & 71,0 & 28,9 & 4,01 & 95,9 & 99,2 & 0,70 & 91,7 & 8,20 \\
\hline 9 & 99,0 & 0,96 & 80,4 & 19,5 & 66,6 & 33,3 & 4,05 & 95,9 & 99,2 & 0,75 & 92,3 & 7,68 \\
\hline \multirow[t]{4}{*}{10} & 98,7 & 1,21 & 80,6 & 19,3 & 62,4 & 37,5 & 4,09 & 95,9 & 99,1 & 0,80 & 92,7 & 7,26 \\
\hline & \multicolumn{4}{|c|}{ TL Cinsi Borç Stoku Modeli } & \multicolumn{4}{|c|}{ YP Cinsi Borç Stoku Modeli } & & & & \\
\hline & \multicolumn{2}{|c|}{$\ln T L B$} & \multicolumn{2}{|c|}{$\ln R D K$} & \multicolumn{2}{|c|}{$\ln Y P B$} & \multicolumn{2}{|c|}{$\ln R D K$} & & & & \\
\hline & $\ln T L B$ & $\ln R D K$ & $\ln T L B$ & $\ln R D K$ & $\ln Y P B$ & $\ln R D K$ & $\ln Y P B$ & $\ln R D K$ & & & & \\
\hline 1 & 100 & 0,00 & 0,05 & 99,9 & 100 & 0,00 & 57,7 & 42,2 & & & & \\
\hline 2 & 97,7 & 2,27 & 0,16 & 99,8 & 99,7 & 0,27 & 77,7 & 22,2 & & & & \\
\hline 3 & 93,9 & 6,03 & 0,23 & 99,7 & 99,5 & 0,45 & 82,7 & 17,2 & & & & \\
\hline 4 & 89,5 & 10,4 & 0,27 & 99,7 & 99,4 & 0,55 & 84,8 & 15,1 & & & & \\
\hline 5 & 84,6 & 15,3 & 0,29 & 99,7 & 99,3 & 0,62 & 86,1 & 13,8 & & & & \\
\hline 6 & 79,6 & 20,3 & 0,30 & 99,6 & 99,3 & 0,67 & 87,0 & 12,9 & & & & \\
\hline 7 & 74,5 & 25,4 & 0,31 & 99,6 & 99,2 & 0,72 & 87,8 & 12,1 & & & & \\
\hline 8 & 69,4 & 30,5 & 0,32 & 99,6 & 99,2 & 0,76 & 88,4 & 11,5 & & & & \\
\hline 9 & 64,5 & 35,4 & 0,32 & 99,6 & 99,1 & 0,80 & 88,9 & 11,0 & & & & \\
\hline 10 & 59,7 & 40,2 & 0,32 & 99,6 & 99,1 & 0,83 & 89,4 & 10,5 & & & & \\
\hline
\end{tabular}


EK 2: Etki-Tepki Fonksiyonları

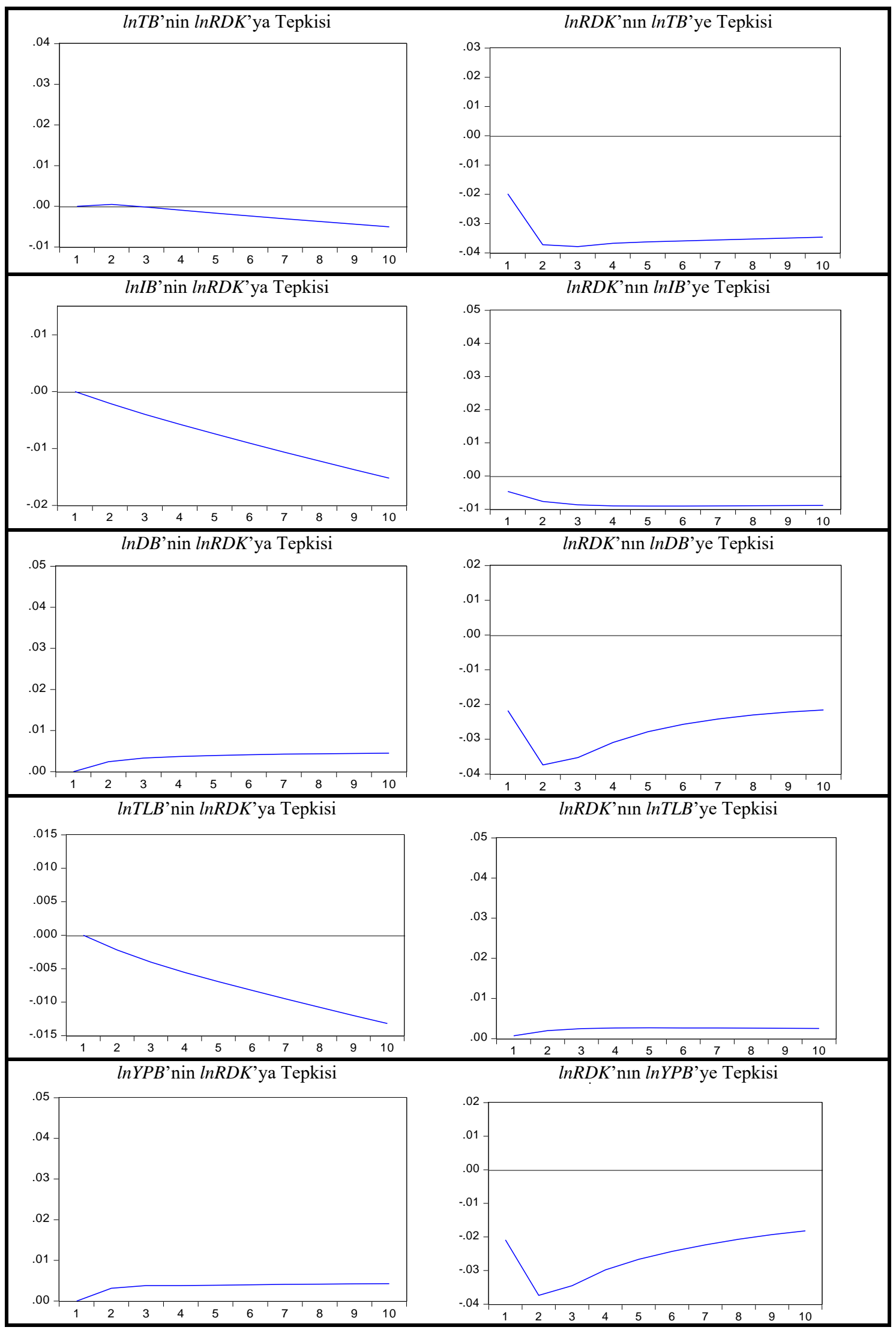

